\title{
$2^{25}$
}

Geochemical Effects of Recharging the Magothy Aquifer,

Bay Park, New York,

With Tertiary-Treated Sewage

GEOLOGICAL SURVEY PROFESSIONAL PAPER 751-D

Prepared in cooperation with the

Nassau County Department of

Public Works

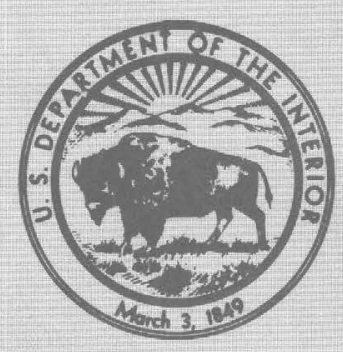





\section{Geochemical Effects of Recharging the Magothy Aquifer, Bay Park, New York, With Tertiary-Treated Sewage}

By STEPHEN E. RAGONE

DEEP-WELL ARTIFICIAL - RECHARGE EXPERIMENTS AT BAY PARK, LONG ISLAND, NEW YORK

GEOLOGICAL SURVEY PROFESIONAL PAPER $751-$ D

Prepared in cooperation with the

Nassau County Department of

Public Works

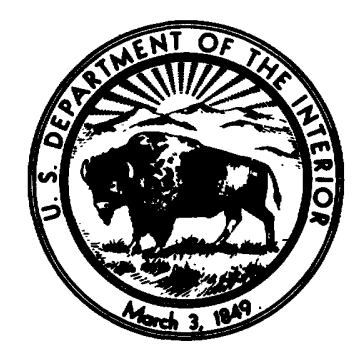




\title{
UNITED STATES DEPARTMENT OF THE INTERIOR
}

\section{CECIL D. ANDRUS, Secretary}

\section{GEOLOGICAL SURVEY}

\author{
V. E. McKelvey, Director
}

\section{Library of Congress Cataloging in Publication Data}

Ragone, Stephen E.

Geochemical effects of recharging the Magothy aquifer, Bay Park, New York, with tertiary-treated sewage.

(Deep-well artificial recharge experiments at Bay Park, Long Island, New York) (Geological Survey professional paper; 751-D)

Bibliography: $p$.

Supt. of Docs. no.: I 19.16:751-D

1. Water chemistry. 2. Aquifers-New York (State)-Bay Park. 3. Sewage. 4. Water, Underground-New York (State)-Bay Park-Artificial recharge. I. Nassau Co., N. Y. Dept. of Public Works. II. Title. III. Series. IV. Series: United States. Geological Survey. Professional paper; 751-D. 


\section{CONTENTS}

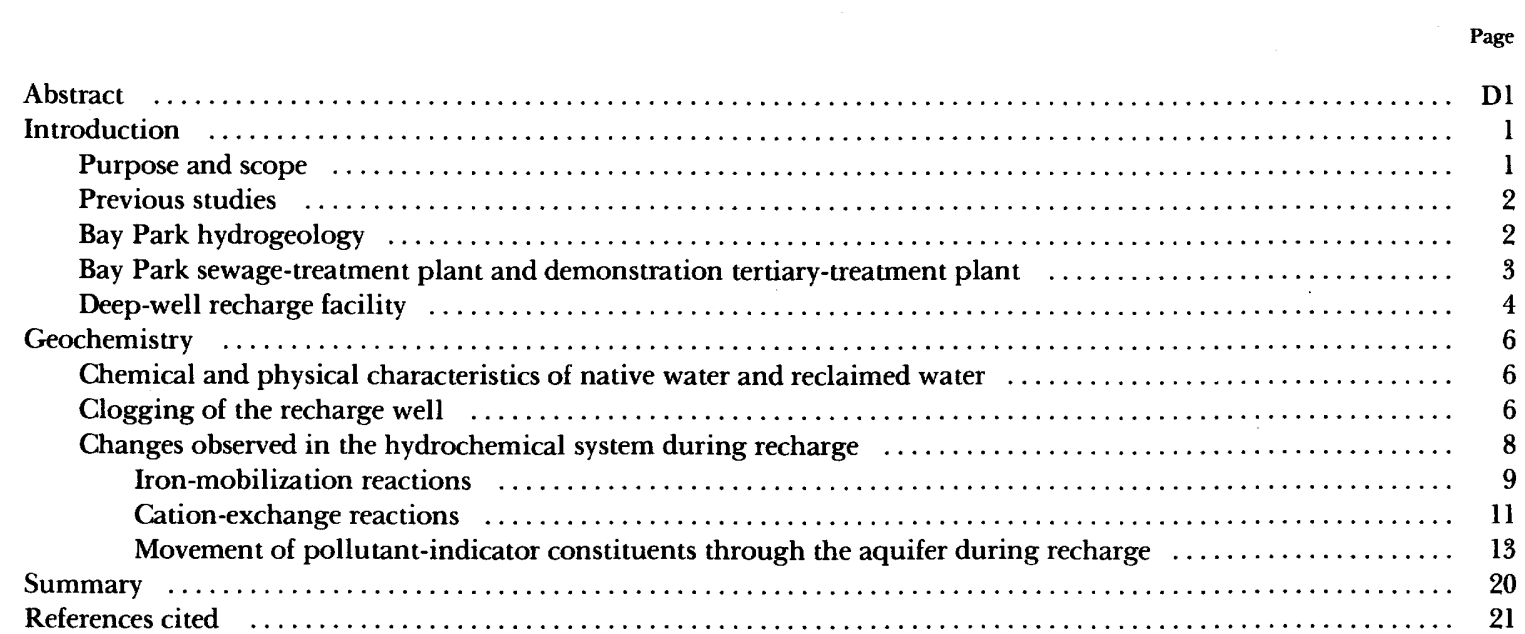

\section{ILLUSTRATIONS}

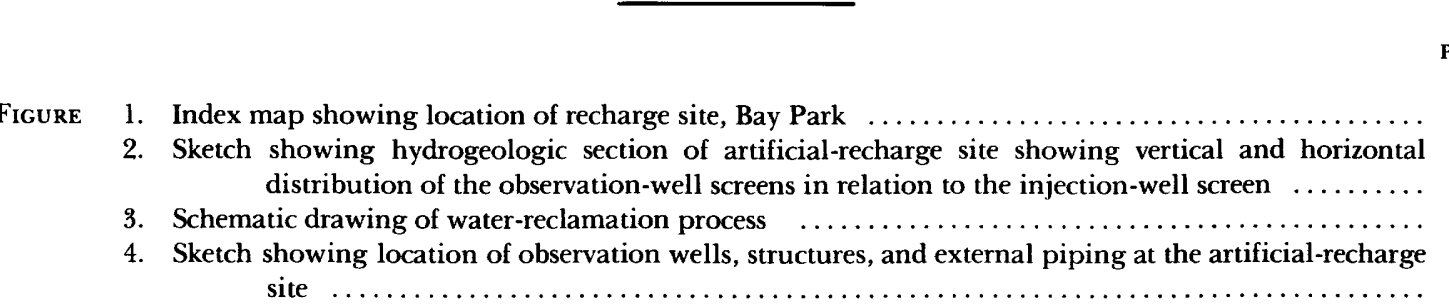
5-14. Graphs showing:

5. Changes in iron concentration and $\mathrm{pH}$ as a function of the fraction of reclaimed water $\left(V_{I}\right)_{\mathrm{Cl}^{-}}$at the 20 -foot $(6.1$-meter) observation well during recharge $\ldots \ldots \ldots \ldots \ldots$

6. Changes in iron concentration and $\mathrm{pH}$ as a function of the fraction of reclaimed water $\left(V_{I}\right)_{\mathrm{Cl}^{-}}$at the 100-foot and 200-foot (30- and 61-meter) observation wells during

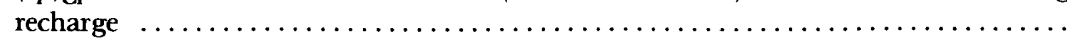

7. Changes in $V_{I}$ values for magnesium and calcium as a function of the fraction of reclaimed water $\left(V_{I}\right)_{\mathrm{Cl}^{-}}$at the 20-foot (6.1-meter) observation well during recharge $\ldots \ldots \ldots \ldots$

8. Changes in $V_{I}$ values for sodium, potassium, ammonium, and bicarbonate as a function of the fraction of reclaimed water $\left(V_{I}\right)_{\mathrm{Cl}^{-}}$at the 20 -foot $(6.1-$ meter $)$ observation well during recharge

9. Changes in $V_{I}$ values for calcium and magnesium as a function of the fraction of reclaimed water $\left(V_{l}\right)_{\mathrm{Cl}^{-}}$at the 100 -foot $(30$-meter) observation well during recharge $\ldots \ldots \ldots \ldots$

10. Changes in $V_{I}$ values for sodium, potassium, ammonium, and bicarbonate as a function of the fraction of reclaimed water $\left(V_{I}\right)_{\mathrm{Cl}^{-}}$at the 100 -foot (30-meter) observation well during

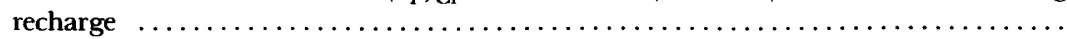

11. Changes in $V_{I}$ values for calcium and magnesium as a function of the fraction of reclaimed water $\left(V_{I}\right)_{\mathrm{Cl}^{-}}$at the 200-foot (61-meter) observation well during recharge $\ldots \ldots \ldots \ldots$

12. Changes in $V_{I}$ values for sodium, potassium, ammonium, and bicarbonate as a function of the fraction of reclaimed water $\left(V_{l}\right)_{\mathrm{Cl}^{-}}$at the 200 -foot (61-meter) observation well during

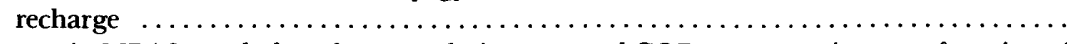

13. Changes in MBAS, total phosphate, total nitrogen, and COD concentrations as a function of the fraction of reclaimed water $\left(V_{I}\right)_{\mathrm{Cl}^{-}}$at the 20 -foot (6.1-meter) observation well during

recharge $\ldots \ldots \ldots \ldots \ldots \ldots \ldots \ldots \ldots \ldots \ldots \ldots \ldots \ldots \ldots \ldots \ldots \ldots \ldots \ldots \ldots \ldots \ldots \ldots \ldots$
14. Changes in MBAS, total phosphate, total nitrogen, and COD concentrations as a function of the fraction of reclaimed water $\left(V_{I}\right)_{\mathrm{Cl}^{-}}$at the 100- and 200-foot (30- and 61-meter) observation wells during recharge 


\section{TABLES}

TABLE 1. Lithologic profile of recharge zone, as determined from cores taken during drilling of the recharge well D4

2. Recharge-test statistics at Bay Park

3. Chemical and physical characteristics of native water from the Magothy aquifer and of reclaimed water 7

4. Selected physical-and chemical-quality parameters of initially recovered water $\ldots \ldots \ldots \ldots \ldots \ldots, 8$

5. Bacterial quality of water recovered after test RW4 in $1969 \ldots \ldots \ldots \ldots \ldots \ldots \ldots \ldots \ldots \ldots$

6. Effect of dissimilar treatments of reclaimed water and city water on the maximum iron concentration of the observed iron peak at the 20 -foot $(6.1$-meter) observation well $\ldots \ldots \ldots \ldots \ldots \ldots \ldots$

7-9. Differences between observed and calculated concentrations of calcium, magnesium, sodium, potassium, ammonium, and hydrogen ions in water from the:

7. 20-foot (6.1-meter) observation well

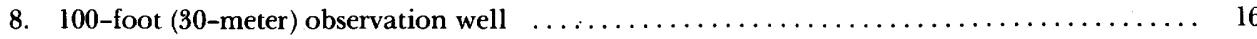

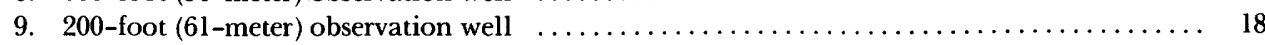

\section{CONVERSION FACTORS}

Factors for converting English units to metric units are shown to three or four significant figures. However, in the text the metric equivalents are shown only to the number of significant figures consistent with the values for the English units.

\begin{tabular}{ll}
\multicolumn{1}{c|}{ English } & Multiply by \\
in (inches) & 25.4 \\
$\mathrm{ft}$ (feet) & $3.048 \times 10^{-1}$ \\
$\mathrm{mi}$ (miles) & 1.609 \\
gal (gallons) & 3.785 \\
$\mathrm{gal} / \mathrm{min}$ (gallons per & $6.308 \times 10^{-2}$ \\
$\quad \mathrm{minute})$ & \\
$\quad \begin{array}{l}\text { [(gal/min)/ft] (gallons } \\
\text { per minute per foot) }\end{array}$ & $2.07 \times 10^{-1}$ \\
Mgal (million gallons) \\
$\begin{array}{l}\text { Mgal/d (million gallons } \\
\text { per day) }\end{array}$ \\
$\quad$
\end{tabular}

Metric

$\mathrm{mm}$ (millimeters)

m (meters)

km (kilometers)

1 (liters)

1/s (liters per

second)

$[(1 / s) / m]$ (liters per

second per meter)

mil 1 (million liters)

$\mathrm{m}^{3} / \mathrm{s}$ (cubic meters

per second) 


\title{
GEOCHEMICAL EFFECTS OF RECHARGING THE MAGOTHY AQUIFER, BAY PARK, NEW YORK, WITH TERTIARY-TREATED SEWAGE
}

\author{
By STEPHEN E. RAgone
}

\begin{abstract}
A ground-water deficit of 93.5 to 123 million gallons per day (4.10 to 5.39 cubic meters per second) has been predicted for Nassau County, N.Y., by the year $\mathbf{2 0 0 0}$ in a State report. Because of the predicted deficit, the U.S. Geological Survey, in cooperation with the Nassau County Department of Public Works, began an experimental deep-well recharge program in 1968. Thirteen recharge tests using tertiary-treated sewage (reclaimed water) and six tests using water from the domestic supply (city water) were completed between 1968 and 1973. Recharge was through an 18-inch (46-centimeter) diameter recharge well screened in the Magothy aquifer between depths of 418 and 480 feet (127 and 146 meters) below land surface. Recharge rates ranged from about 200 to 400 gallons per minute (13 to 25 liters per second). In the longest test, reclaimed water was injected during 84.5 days of a 199-day period.

Although the iron concentration of native water in the recharge zone and of reclaimed water is less than 0.5 milligrams per liter, the iron concentration of samples collected from observation wells 20,100 , and 200 feet $(6.1,30$, and 61 meters) from the recharge well, and screened in the zone of recharge, approached 3 milligrams per liter at times. Iron mass-
\end{abstract}

\begin{abstract}
balance calculations indicate that dissolution of pyrite and marcasite $\left(\mathrm{FeS}_{2}\right)$ in the aquifer are the only known sources of iron that could explain the observed increase. Within a 20 -foot $(6.1$-meter) radius of the recharge well, dissolved oxygen in the reclaimed water oxidizes pyrite and releases $\mathrm{Fe}^{+2}$ (ferrous iron) to solution. However, the amount of iron in water continues to increase with distance from the recharge well even though dissolved oxygen is no longer present in water reaching the 20foot (6.1-meter) radius; the mechanism by which iron continues to be dissolved is not quantitatively understood.

Some cation exchange also occurs during recharge. Loss of ammonium and potassium cations in the water was balanced by an increase in $\mathrm{H}^{+}$, which at times caused $\mathrm{pH}$ to decrease by more than $1 \mathrm{pH}$ unit.

Tertiary treatment removes 90 to 98 percent of the phosphate, MBAS (methylene blue active substances), and COD (chemical oxygen demand), leaving an average of $0.17,0.07$, and 9 milligrams per liter, respectively. During recharge, phosphate concentrations remain at native-water levels at the 20-, 100-, and 200-foot (6.1-, 30-, and 61-meter) observation wells, which indicates phosphate retention by the aquifer. Some MBAS and COD are retained at the 100- and 200-foot (30- and 61meter) wells, presumably by adsorption reactions.
\end{abstract}

\section{INTRODUCTION}

Population of Nassau County, Long Island, N.Y. (fig. 1) increased from 0.41 million in 1940 to 1.43 million in 1970 and is expected to increse to between 1.63 and 1.85 million by the year 2000 (Temporary State Commission on the Water-Supply Needs of Southeastern New York, 1972). As a result of population increase, gross pumpage from the ground-water system, the only source of public water supply to date (1977), has increased from $75 \mathrm{Mgal} / \mathrm{d}$ (3.29 $\left.\mathrm{m}^{3} / \mathrm{s}\right)$ in 1940 to $215 \mathrm{Mgal} / \mathrm{d}\left(9.42 \mathrm{~m}^{3} / \mathrm{s}\right)$ in 1970 . Gross pumpage is expected to range from 258 to $313 \mathrm{Mgal} / \mathrm{d}$ (11.3 to $13.7 \mathrm{~m}^{3} / \mathrm{s}$ ) by the year 2000 (Temporary State Commission on the Water-Supply Needs of Southeastern New York, 1972). The increased demand for water-together with decreased recharge resulting from the replacement of cesspools and septic tanks, which return effluents to the ground, with sewer systems, which discharge effluents offshore-is predicted to cause a water deficit in Nassau
County of 93.5 to $123 \mathrm{Mgal} / \mathrm{d}\left(4.10\right.$ to $\left.5.39 \mathrm{~m}^{3} / \mathrm{s}\right)$ by the year 2000 (Temporary State Commission on the Water-Supply Needs of Southeastern New York, 1972).

\section{PURPOSE AND SCOPE}

This report summarizes the geochemical effects of injecting reclaimed water (tertiary-treated sewage) into a sand aquifer. Because of the very good chemical quality of the native water, as reflected by a dissolved-solids concentration of 22 to $25 \mathrm{mg} / 1$ (milligrams per liter), it was necessary to determine the type and extent of any chemical reaction caused by artificial recharge that could lead to a degradation of water quality. The study began in 1964 and was completed in 1973 as part of a cooperative water-resources program between the U.S. Geological Survey and the Nassau County Department of Public Works. Thirteen 


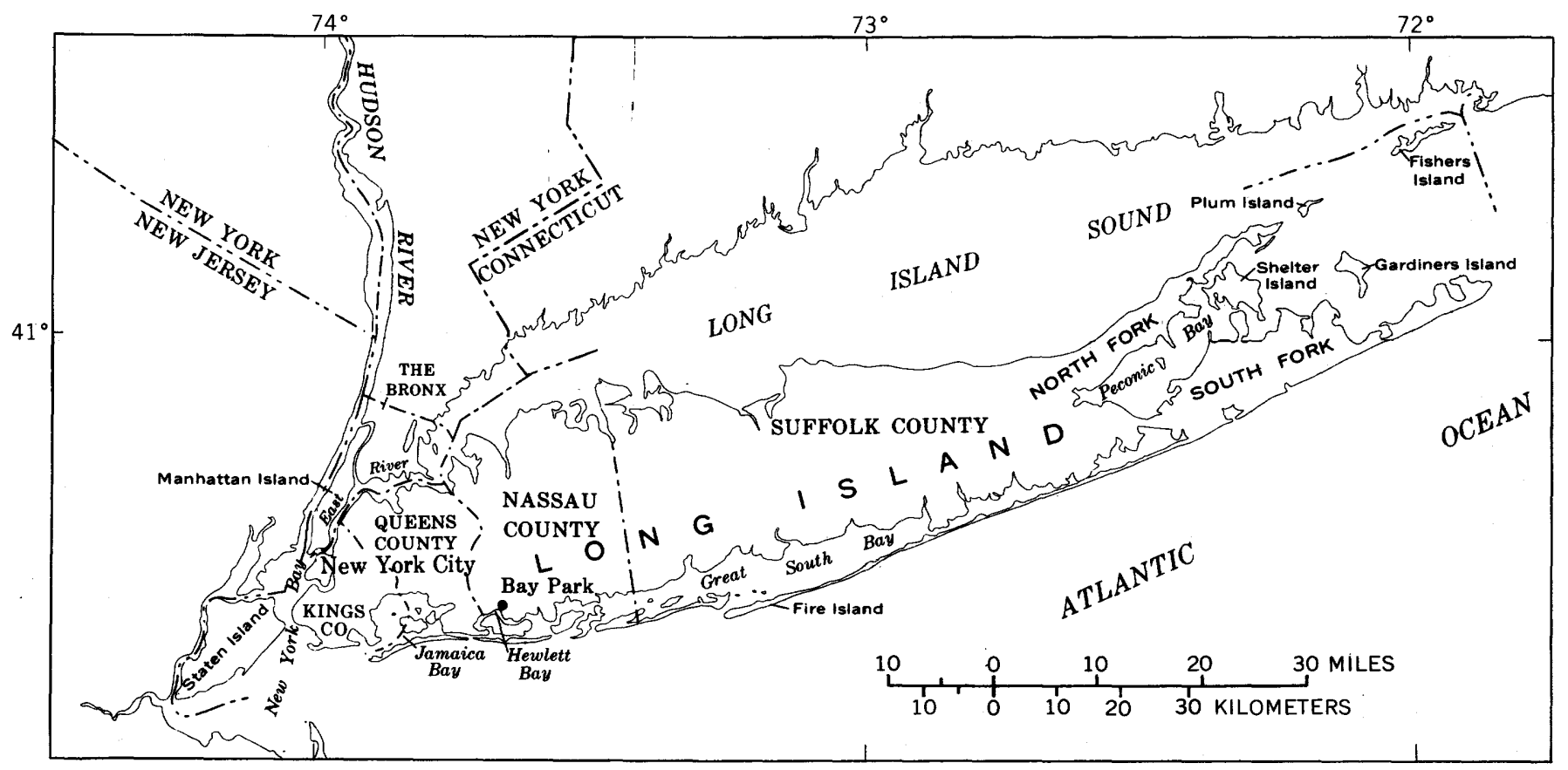

Figure 1.-Location of recharge site, Bay Park, New York.

tests using reclaimed water and six tests using city water (water from the domestic supply) were completed between 1968 and 1973. Chemical and hydrologic data were collected from all the tests, but most of the geochemical data for this report were obtained from the last and longest recharge test, in which reclaimed water was injected during 84.5 days of the 199-day period from October 24, 1972, to May 11, 1973.

\section{PREVIOUS STUDIES}

Several reports covering different aspects of the Bay Park project have been published. Details of design, construction, and operation of the recharge facility have been reported by Cohen and Durfor (1966 and 1967), Perlmutter and others (1968), and Koch and others (1973). Several studies of the microbiological aspects of deep-well recharge have been reported by Vecchioli (1970), Vecchioli and others (1972), and Ehrlich and others (1972 and 1973). Description of early findings are given in reports by Vecchioli and Ku (1972), Vecchioli (1972), and Vecchioli and others (1974). Some of the water-quality changes during recharge have been reported by $\mathrm{Ku}$ and others (1975), Faust and Vecchioli (1974), Ragone and others (1973 and 1975), and Ragone and Vecchioli (1975). The corrosivity of water with respect to metals was also reported by Vecchioli and Giaimo (1972), and a comprehensive review of the operation and general results of the Bay Park project is given by Vecchioli and others (1975).

\section{BAY PARK HYDROGEOLOGY}

Long Island is underlain by consolidated bedrock, which, in turn, is overlain by a wedge-shaped mass of unconsolidated Pleistocene glacial deposits and Cretaceous fluvial or deltaic deposits. This unconsolidated material, which constitutes the ground-water reservoir for Long Island, ranges in thickness from $0 \mathrm{ft}$ in northwest Queens County, where bedrock crops out, to more than $2,000 \mathrm{ft}(610 \mathrm{~m})$ in southern Suffolk County (Cohen and others, 1968, p. 18). The ground-water reservoir consists of several aquifers, of which the Magothy aquifer is the principal water-supply source for Nassau County.

The recharge well at Bay Park, N7884, is screened in a zone in the Magothy aquifer (fig. 2) that is semiconfined by beds of lower hydraulic conductivity. Static water level in this zone is approximately $5 \mathrm{ft}(1.5 \mathrm{~m})$ below land surface. In this zone, the aquifer consists of gray very fine to medium sand and contains some silt and clay layers (table 1). X-ray analysis of a sample taken at a depth of $527 \mathrm{ft}$ (161 $\mathrm{m}$ ) during the drilling of the test hole that preceded drilling of the recharge well shows that the clay in this sample is composed of equal parts of kaolinite and illite (Vecchioli and others, 1974); presumably, therefore, clay is of this composition throughout the recharge zone. Lignite occurs in layers and as disseminated particles. Pyrite and marcasite $\left(\mathrm{FeS}_{2}\right)$ are also present and, in many places, are associated with lignite. Other accessory minerals include muscovite, tourmaline, garnet, zircon, andalusite, and sillimanite (Vecchioli and others, 1974). Carbonate miner- 


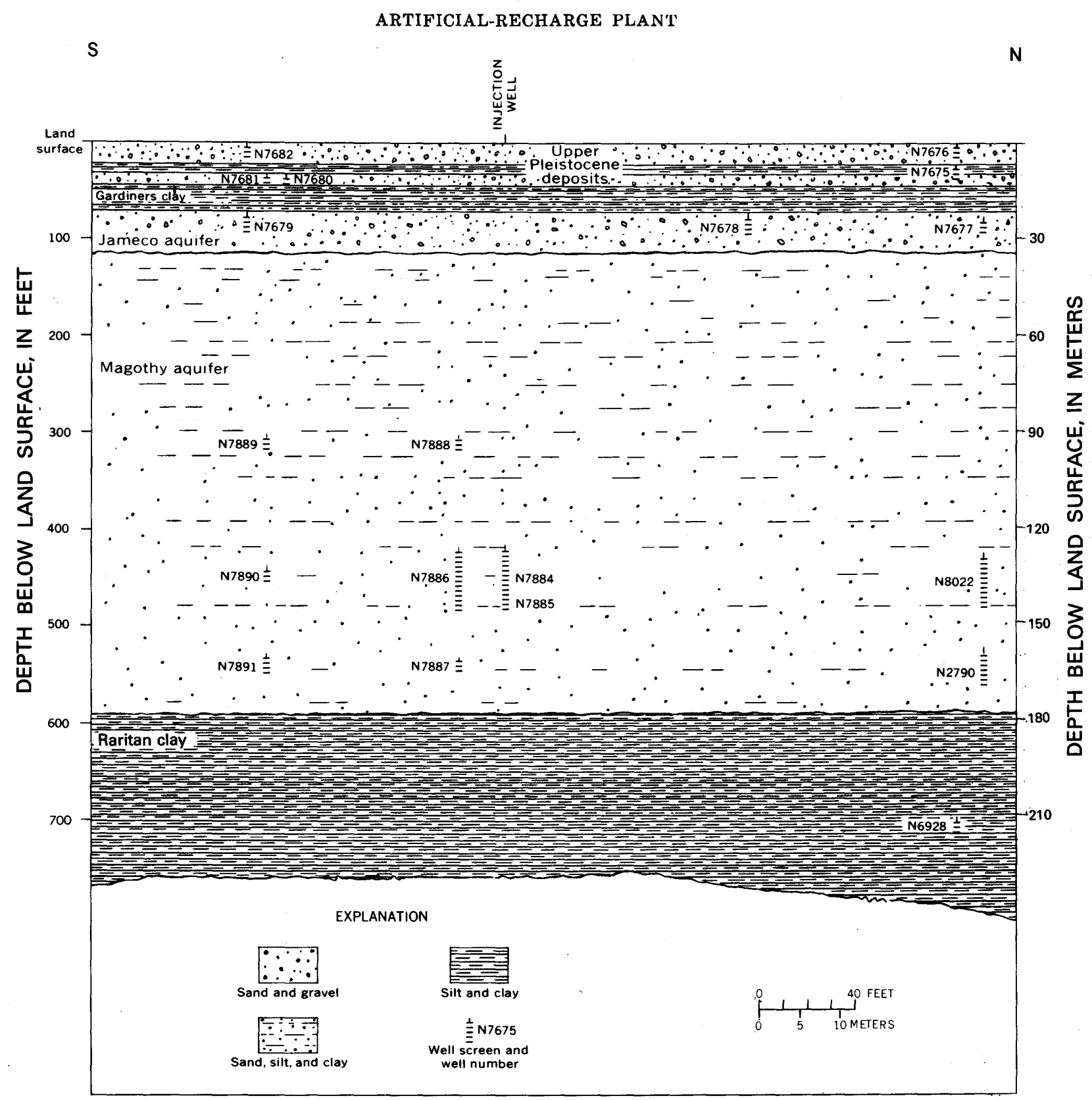

FIGURE 2.-Hydrogeologic section of artificial-recharge site showing vertical and horizontal distribution of the observation-well screens in relation to the injection-well screen (from Koch and others, 1973, fig. 9).

als are absent from the vicinity of the recharge zone (Vecchioli and others, 1974).

The predominant directions of ground-water movement are northward and southward from the groundwater divide near the central axis of the island. Detailed information about Long Island's hydrogeology is presented in several reports (for example, Franke and McClymonds, 1972; Perlmutter and Geraghty, 1963). Near the south shore of Long Island, the ground-water flow pattern is that of discharge-freshwater moves outward and upward into the bays and ocean. Thus, the water presently in the Magothy aquifer at this site is derived from precipitation that infiltrated the aquifer $1 \mathrm{mi}(1.6 \mathrm{~km})$ or more to the north hundreds of years ago (Franke and Cohen, 1972, p. C271).

\section{BAY PARK SEW AGE-TREATMENT PLANT AND DEMONSTRATION TERTIARY-TREATMENT PLANT}

The Bay Park sewage-treatment plant is a $60-\mathrm{Mgal} / \mathrm{d}$ $\left(2.6-\mathrm{m}^{3} / \mathrm{s}\right)$, conventional, activated-sludge treatment plant. About 1 percent of the secondary effluent from the 
TABLE 1.-Lithologic profile of recharge zone, as determined from cores taken during drilling of the recharge well

[From Vecchioli and others, 1974, p. C6]

Thickness
(feet)

Depth below land surface

392 436

Bay Park plant is diverted to a $400-\mathrm{gal} / \mathrm{min}(25 \mathrm{l} / \mathrm{s})$ demonstration tertiary-treatment plant. There, the water receives physical-chemical treatment to produce virtually potable water (Peters and Rose, 1968). The general process is as follows (fig. 3). Influent from the activated-sludge plant enters a reactivator-clarifier tank, where it is treated with alum (aluminum sulfate) to precipitate phosphate and suspended solids. The supernatant liquid is then pumped through dual-media sand filters to remove additional suspended solids, then through from one to four activated carbon columns to remove dissolved organic materials. The final step in the tertiary-treatment process is chlorination.

\section{DEEP-WELL RECHARGE FACILITY}

Effluent from the tertiary-treatment plant is pumped approximately $0.5 \mathrm{mi}(0.8 \mathrm{~km})$ to the recharge site. Influent from
activated sl
plant
Detailed descriptions of design and operation of this facility are given by Koch and others (1973), Perlmutter and others (1968), and Cohen and Durfor (1966 and 1967); therefore, only a brief description is given here.

The facility consists of (1) a 50,000-gal (189,000-1) storage tank; (2) a recharge well with an 18-in (46-cm) diameter fiberglass casing and a 16-in (41-cm) -diameter by $62-\mathrm{ft}(19-\mathrm{m})$-long stainless steel screen between depths of 418 and $480 \mathrm{ft}$ ( 127 and $146 \mathrm{~m}$ ); (3) various equipment for further treating reclaimed water or city water (dechlorination, degassing, and $\mathrm{Eh} / \mathrm{pH}$ adjustments); and (4) 18 observation wells ranging from several inches to $200 \mathrm{ft}$ (61 $\mathrm{m}$ ) from the recharge well and screened at various depths. Most of the data collected during the recharge tests were obtained from samples from the recharge well, N7884, and three observation wells that were screened within the zone of recharge; these wells are designated N7886, N7890, and N8022. Wells N7886 and N7890 are $20 \mathrm{ft}(6.1 \mathrm{~m})$ and $100 \mathrm{ft}$ $(30 \mathrm{~m})$ southwest of the recharge well, respectively (fig. 4). Well N8022 is $200 \mathrm{ft}(61 \mathrm{~m})$ northeast of the recharge well.

The recharge well and the observation wells are constructed of nonferrous or corrosion-resistant materials to minimize the possibility of chemical reaction of the reclaimed water with the wells (Cohen and Durfor, 1966). To permit additional experimentation, the system is designed to allow injection of city water as well as reclaimed water.

Six recharge tests with city water and 13 recharge tests with reclaimed water were completed between 1968 and 1973 (table 2). These tests ranged in length from 2 to 84.5 days; recharge rates were from about 200 to $400 \mathrm{gal} / \mathrm{min}$ (13 to $25 \mathrm{l} / \mathrm{s}$ ); and treatment process in the tertiary plant and (or) at the recharge site was also varied. Test RW10 consisted of two separate periods of recharge but is considered as one test because redevelopment between recharge periods was very slight and did not return the aquifer to natural conditions as it did after the other tests.

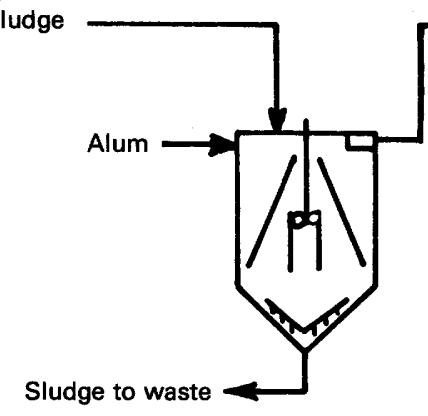
Sludge to waste REACTIVATOR-CLARIFIER

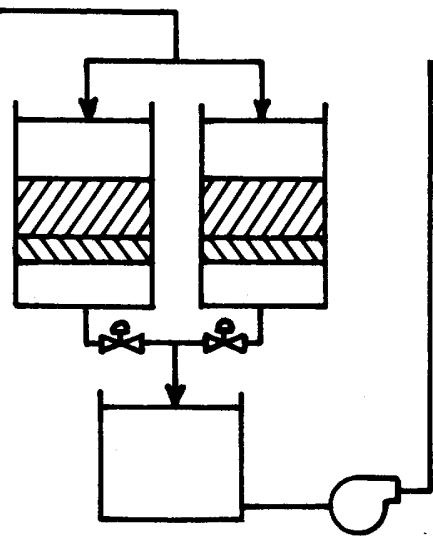

DUAL MEDIA

FILTRATION

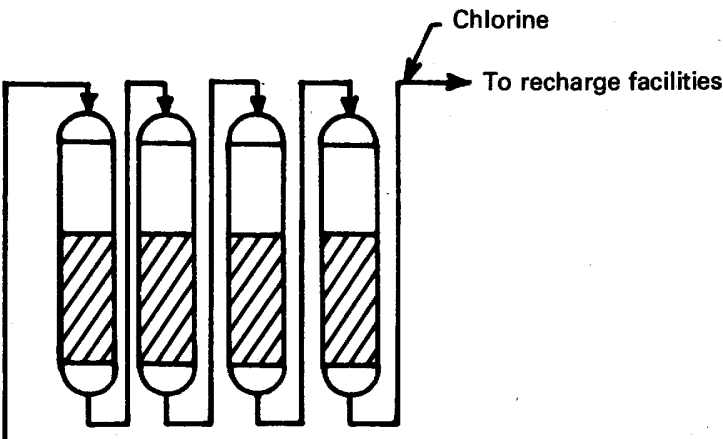

ADSORPTION ON ACTIVATED CARBON

FigURE 3.-Schematic drawing of water-reclamation process (from Vecchioli and others, 1975, fig. 1). 


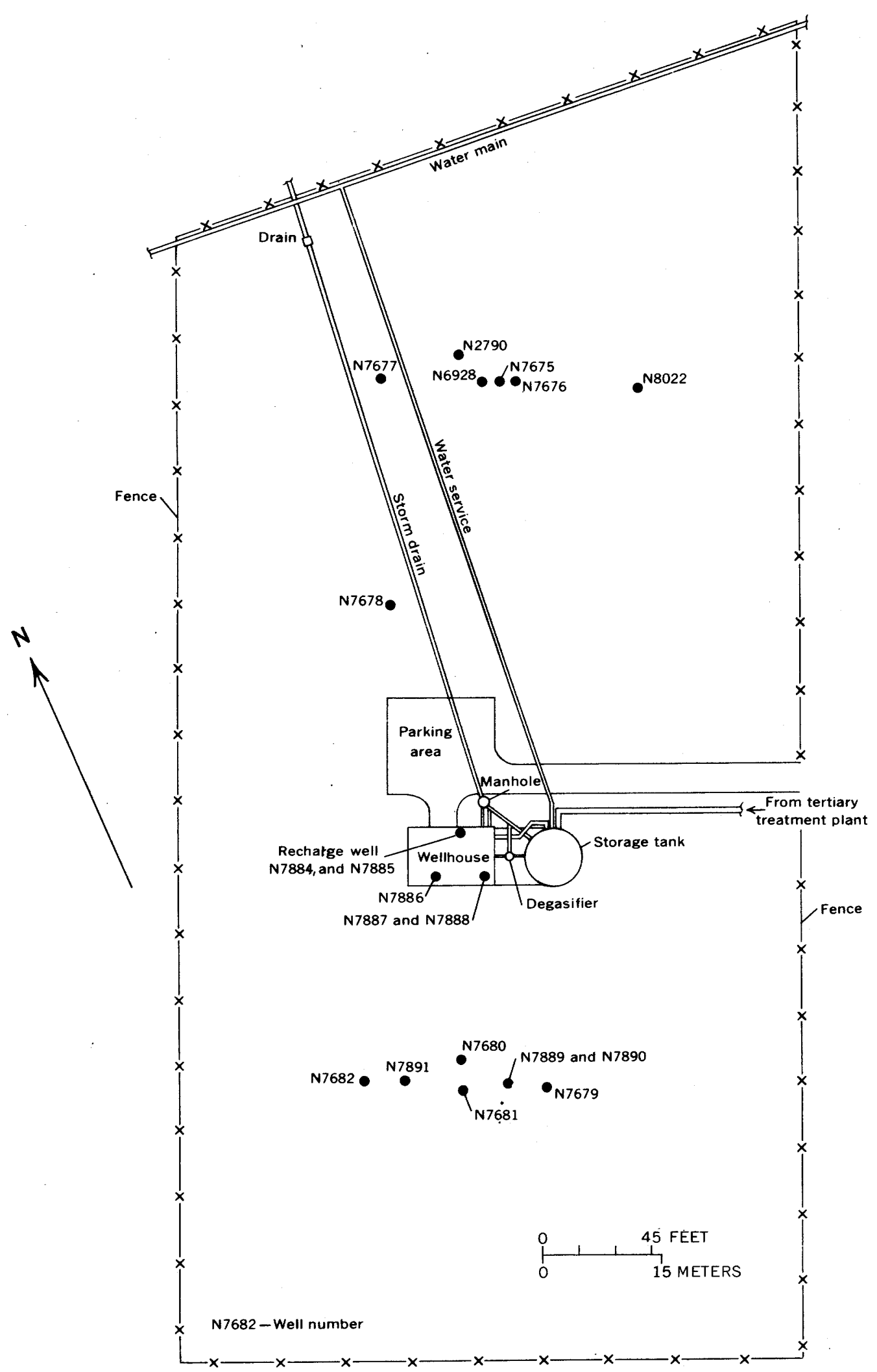

FIGURE 4.-Location of observation wells, structures, and external piping at the artificial recharge site (from Koch and others, 1973, fig. 8). 


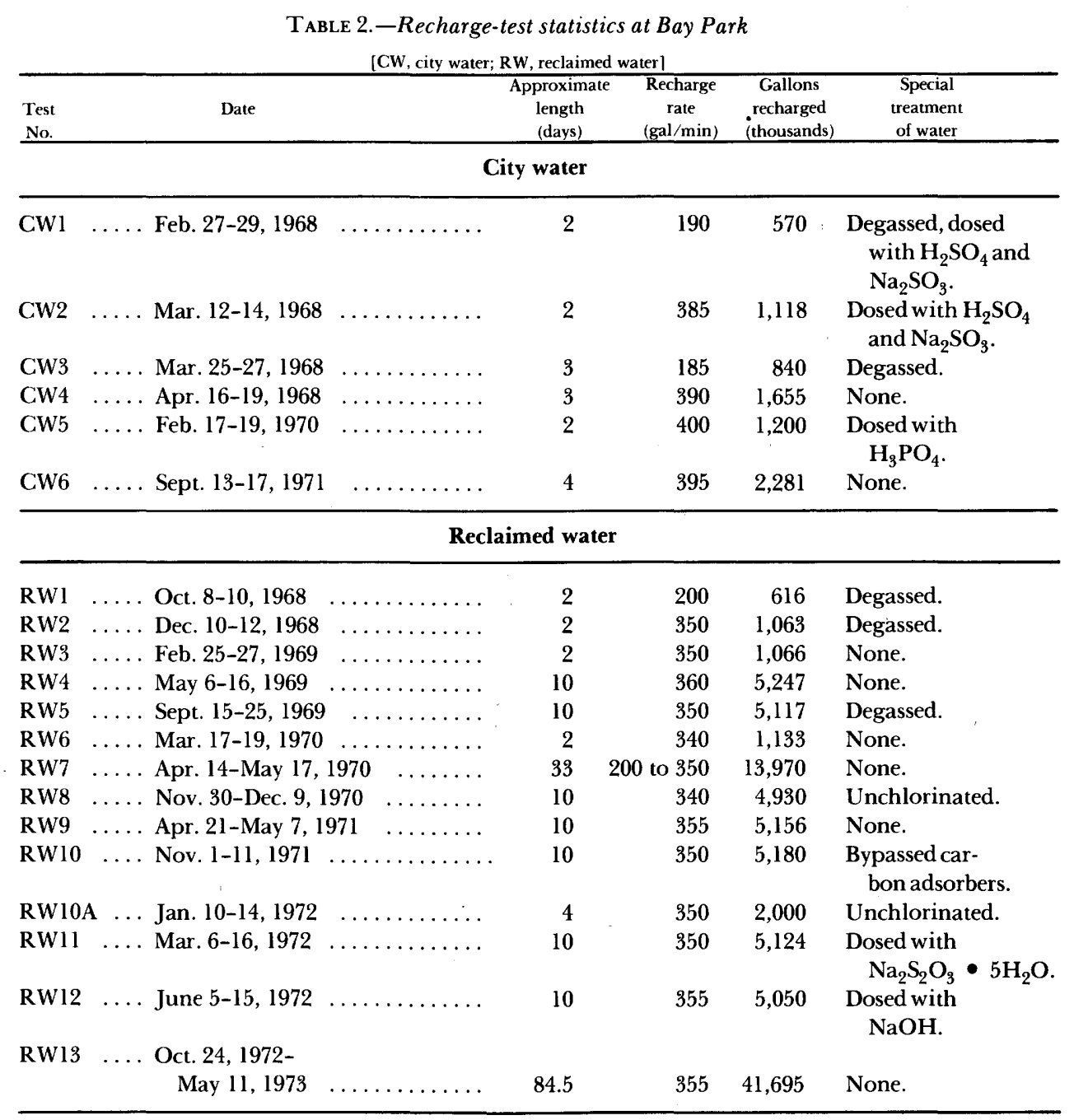

Effects of the different treatment processes are described where appropriate in the following sections.

\section{GEOCHEMISTRY}

\section{CHEMICAL AND PHYSICAL CHARACTERISTICS OF NATIVE WATER AND RECLAIMED WATER}

Dissolved-solids concentration of native water in the Magothy aquifer ranges from 22 to $25 \mathrm{mg} / 1$ (table 3 ), and $\mathrm{pH}$ ranges from 5.22 to 5.72 . Clay minerals, mainly kaolinite, control the concentration of the alkali and alkaline earth elements through cation exchange (Pearson and Friedman, 1970). Concentration of $\mathrm{SiO}_{2}$ (silica) in solution approaches that in thermodynamic equilibrium with quartz. The concentrations of $\mathrm{Fe}^{+2}$ (divalent iron) and $\mathrm{SO}_{4}^{-2}$ (sulfate) in solution are controlled by thermodynamic equilibrium with pyrite (Vecchioli and others, 1974; Faust and Vecchioli, 1974). The $\mathrm{pH}$ of the water is controlled by both the dissociation of $\mathrm{H}_{2} \mathrm{CO}_{3}$ (carbonic acid) and the silica-kaolinite equilibrium (Faust and
Vecchioli, 1974). Carbon dioxide partial pressure of water in the recharge zone at Bay Park is one to two orders of magnitude greater than that of water in equilibrium with air (Faust and Vecchioli, 1974; Pearson and Friedman, 1970); plant sources rather than carbonate minerals cause this increase (Pearson and Friedman, 1970; Vecchioli and others, 1974). DO (dissolved oxygen) concentration of native water is zero, and Eh (oxidation-reduction potential) of the water ranges from -0.03 to -0.10 volts.

Concentrations of most constituents of the reclaimed water are greater than in native water from the Magothy aquifer (table 3 ).

\section{CLOGGING OF THE RECHARGE WELL}

Specific capacity at the end of each of the 13 recharge tests was less than at the start because of physical-chemical and (or) biological processes that caused entrapment of suspended material either in the gravel pack, at the well screen-aquifer interface, or within the first several inches of the aquifer. In physical-chemical clogging, suspended 
TABLE 3.-Chemical and physical characteristics of native water from the Magothy aquifer and of reclaimed water

[All data in milligrams per liter unless otherwise indicated; N.D., not determined]

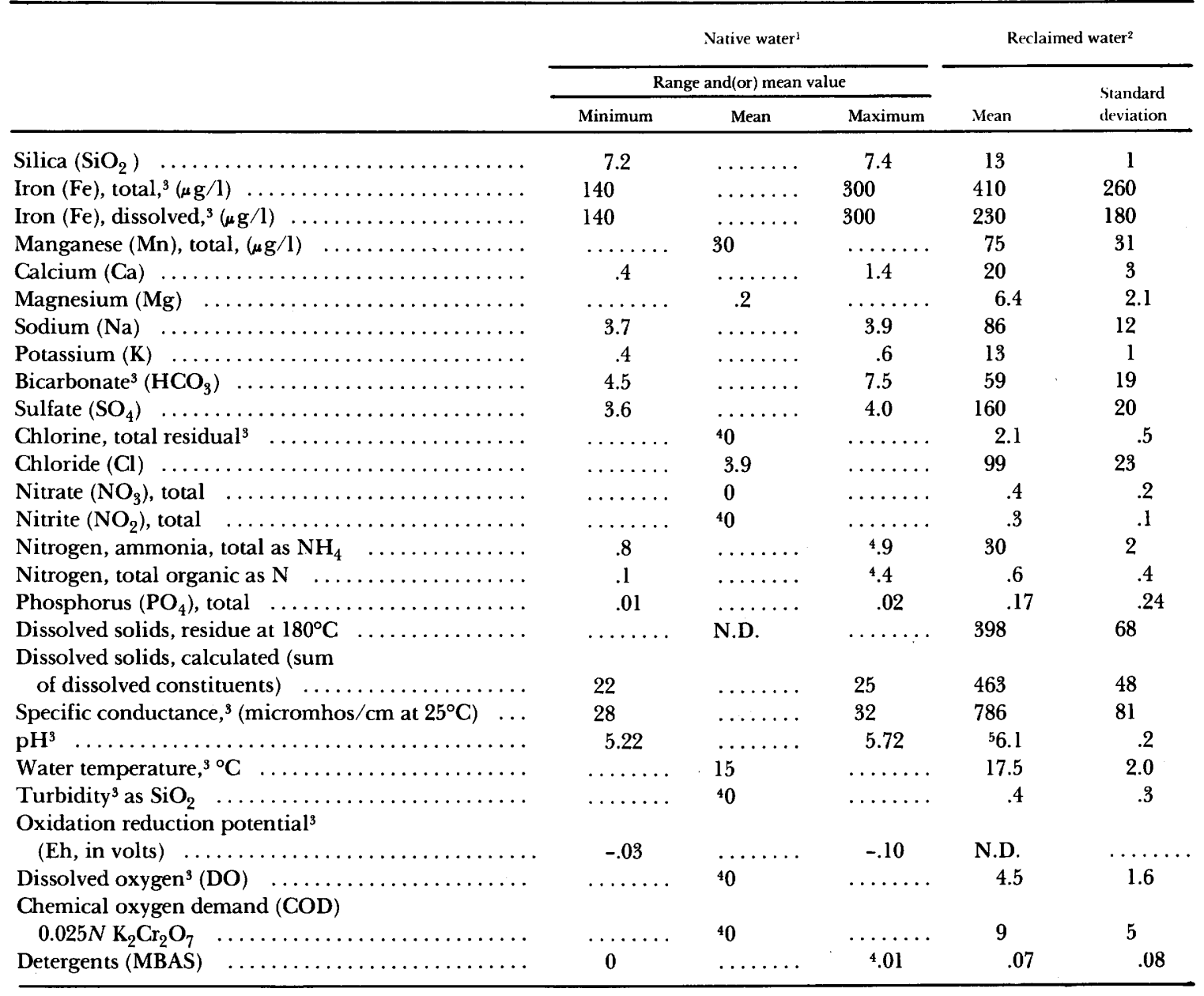

'After Vecchioli and others (1974), for samples taken from the 20-, 100-, and 200-ft (6.1-, 30-, and 61-m)

observation wells before any recharge, unless otherwise stated.

${ }^{2}$ Based on the weighted average of at least 33 daily or weekly composite samples.

${ }^{3}$ Measured or determined on site.

${ }^{4}$ Data from RW10 (reclaimed-water test 10).

${ }^{5}$ Mean calculated after converting $\mathrm{pH}$ values from logarithmic form to exponential form.

material may originate in secondary sewage or may be formed during the tertiary-treatment process. Neither purely physical clogging caused by gas entrapment nor purely chemical clogging caused by chemical incompatibilities between the reclaimed water and native water and aquifer have been observed at Bay Park. Biological clogging has been observed (Ehrlich and others, 1973), but this type of clogging can be controlled by chlorination (Ehrlich and others, 1972 and 1973).

Studies during tests RW1 through RW7 (the first 7 of the 13 recharge tests with reclaimed water) indicate a correlation between turbidity of the reclaimed water and the rate of well clogging (Vecchioli and $\mathrm{Ku}, 1972$; Vecchioli, 1972; Vecchioli and others, 1975). The water initially repumped from the recharge well was turbid and, at times, odorous. Chemical and microbiological analyses indicated that it contained high concentrations of iron, phosphate, volatile and fixed suspended solids (table 4), and bacteria (table 5). Water quality improved markedly with continued repumping but often deteriorated after the pumping rate was rapidly varied. This suggests that material close to the well bore was being dislodged by the surging action.

The high concentration of iron and phosphate in the repumped water suggests that iron hydroxy phosphates, which are formed in the coagulation step of tertiary treatment, pass through the sand filters (which are coarser than the aquifer material) and are trapped near the gravel pack-aquifer interface. Processing the chemical data by application of WATEQ, the computer program of Truesdall and Jones (1974), showed that the repumped water was supersaturated with aluminum and iron hydroxy species and iron oxide species. Precipitation of some or all 


\begin{tabular}{|c|c|c|c|c|c|}
\hline & RW1 & $\mathrm{RW} 2$ & RW3 & RW4 & RW5 \\
\hline liurbidity $\ldots . . .$. & $\ldots \ldots \ldots \ldots \ldots 225$ & 78 & 5 & 80 & ${ }^{2} 163$ \\
\hline lotal phosphate & $\ldots \ldots \ldots \ldots, 30$ & 26 & 1.44 & 19.6 & 43.5 \\
\hline Iital iron $\ldots . .$. & $\ldots \ldots \ldots \ldots \ldots 45.5$ & 7.55 & .08 & 15.1 & 50.5 \\
\hline Toltat solids... . & . ...........6 672 & 513 & ...... & .532 & 686 \\
\hline \multicolumn{6}{|c|}{ Total suspended } \\
\hline solids ........ & ......... 328 & 136 & 6 & 84 & 248 \\
\hline \multicolumn{6}{|l|}{ Contal dissolved } \\
\hline sotids $\ldots . .$. & ........344 & 377 & 381 & 448 & 438 \\
\hline \multicolumn{6}{|l|}{ Tot:al volatile } \\
\hline solids $\ldots . .$. & $\ldots \ldots \ldots 171$ & 146 & & .132 & 232 \\
\hline \multicolumn{6}{|l|}{ V'olatile suspended } \\
\hline solids $\ldots \ldots \ldots$ & $\ldots \ldots \ldots 116$ & 50 & $\ldots \ldots$ & 37 & 82 \\
\hline \multicolumn{6}{|l|}{ V'oliatile dissolved } \\
\hline solisds $\ldots \ldots \ldots$ & $\ldots \ldots \ldots 55$ & 96 & $\ldots \ldots$ & .95 & 150 \\
\hline \multicolumn{6}{|l|}{ Tetal fixed } \\
\hline solids $\ldots . .$. & $\ldots \ldots \ldots 501$ & 367 & & .400 & 454 \\
\hline \multicolumn{6}{|l|}{ liixed suspended } \\
\hline solids $\ldots \ldots \ldots$ & $\ldots \ldots 212$ & 86 & & .47 & 166 . \\
\hline \multicolumn{6}{|l|}{ Fixed dissolved } \\
\hline olisds $\ldots \ldots \ldots$ & $\ldots \ldots \ldots \ldots \ldots 289$ & 281 & & .353 & 288 \\
\hline Oxygen consumed & $\ldots \ldots \ldots \cdots^{3} 48$ & 35 & 15 & 36 & ${ }^{2} 21$ \\
\hline
\end{tabular}

of these species probably explains the accumulation of iron- and aluminum-rich solids around the aquifer-well screen interface in previous recharge experiments. Ragone and others (1973) found that the amount of iron recovered from the recharge well during repumping after test RW10 was equal to the amount of colloidal iron in the reclaimed water initially recharged.

Acid treatment of the recharge well rreatly improved specific capacity (Vecchioli, 1972). After test RW7, specific capacity was $2.5(\mathrm{gal} / \mathrm{min}) / \mathrm{ft}[0.52(1 / \mathrm{s}) / \mathrm{m}]$, down from $23.5(\mathrm{gal} / \mathrm{min}) / \mathrm{ft}[4.9(\mathrm{l} / \mathrm{s}) / \mathrm{m}]$ at the start of the test. Stepwise surges in pumping at rates ranging from 300 $\mathrm{gal} / \mathrm{min}(19 \mathrm{l} / \mathrm{s})$ to $1,000 \mathrm{gal} / \mathrm{min}(63 \mathrm{l} / \mathrm{s})$ increased specific capacity to $18(\mathrm{gal} / \mathrm{min}) / \mathrm{ft}[3.7(\mathrm{l} / \mathrm{s}) / \mathrm{m}]$. Approximately 2,400 gal $(9,084$ l) of 32 -percent commercial-grade hydrochloric acid was then pumped into the well and was pumped out after standing approximately 20 hours; this treatment increased specific capacity to $26.5(\mathrm{gal} / \mathrm{min}) / \mathrm{ft}$ $[5.5(1 / \mathrm{s}) / \mathrm{m}]$.

A long-term redevelopment (pumping out) of the recharge well followed each recharge experiment in order to return the system to pretest condition. Nearly 50 percent more water had to be pumped out than had been injected in order to attain this.

\begin{tabular}{|c|c|c|c|c|}
\hline \multicolumn{5}{|c|}{$\begin{array}{l}\text { [Analyses by Nassau County Department of Health. } \\
\text { Intermittent pumping from 6-5 to 6-23; pauses from } \\
6-27 \text { to } 7-1,7-1 \text { to } 7-15,7-16 \text { to } 8-6 \text { ] }\end{array}$} \\
\hline Datce & & $\begin{array}{l}\text { Cumulative } \\
\text { gallons } \\
\text { withdrawn } \\
\text { (thousands) }\end{array}$ & $\begin{array}{l}\text { Standard plate } \\
\text { count at } 35^{\circ} \mathrm{C} \\
\text { (number } / \mathrm{ml})\end{array}$ & $\begin{array}{c}\text { Coliform } \\
\text { confirmed } \\
\left(\mathrm{MPN}^{2} / 100 \mathrm{ml}\right)\end{array}$ \\
\hline \multirow{4}{*}{\multicolumn{2}{|c|}{$6-2-69$}} & 2 & $>300$ & $>240$ \\
\hline & & 6 & $>300$ & $>240$ \\
\hline & & 24 & $>300$ & $>240$ \\
\hline & & 86 & $>300$ & $>240$ \\
\hline \multirow[t]{2}{*}{$6-3-69$} & $\ldots$ & 576 & $>300$ & $>240$ \\
\hline & & 883 & 44 & 240 \\
\hline \multirow[t]{2}{*}{$6-4-69$} & $\cdots \cdots$ & 1,483 & $<30$ & 240 \\
\hline & & 1,699 & $<30$ & 240 \\
\hline $6-5-69$ & & 2,299 & $<30$ & 38 \\
\hline \multirow[t]{2}{*}{$6-23-69$} & $\ldots \ldots \ldots \ldots$ & 7,207 & $>300$ & $>240$ \\
\hline & & 7,327 & $<30$ & 38 \\
\hline $6-27-69$ & $\ldots$ & 10,580 & $<30$ & 5 \\
\hline \multirow[t]{2}{*}{$7-1-69$} & $\ldots \ldots \ldots \ldots$ & 10,586 & $>300$ & $>240$ \\
\hline & & 10,676 & $<30$ & 8.8 \\
\hline \multirow[t]{2}{*}{$7-15-69$} & $\cdots$ & 10,682 & $>300$ & $>240$ \\
\hline & & 10,778 & 88 & 2.2 \\
\hline $7-16-69$ & & 11,253 & $<30$ & $<2.2$ \\
\hline \multirow[t]{2}{*}{$8-6-69$} & $\ldots \ldots \ldots$ & 11,346 . & $\ldots \ldots \ldots \ldots \ldots$ & 38 \\
\hline & & 11,438 . & $\ldots \ldots$ & $<2.2$ \\
\hline $8-7-69$ & $\ldots \ldots \ldots \ldots$ & 11,918 . & $\ldots \ldots \ldots \ldots \ldots$ & $<2.2$ \\
\hline
\end{tabular}

Table 7, from Vecchioli and $\mathrm{Ku}$ (1972).

: Most probable number.

\section{CHANGES OBSERVED IN THE HYDROCHEMICAL SYSTEM DURING RECHARGE}

A simplified aquifer-flow model, although it does not exactly depict the actual flow, was used to define the movement of reclaimed water through the aquifer. With the model, reclaimed water is assumed to move radially away from the recharge well as an expanding cylinder the same height and at the same depth as the screened interval of the recharge well. Analysis of pumping-test data (Vecchioli and others, 1974) shows that within a 200-ft (61$\mathrm{m}$ ) radius of the recharge well, flow follows a nearly horizontal-radial pattern.

On the basis of the radial-flow model and on the assumption that the mineralogy of the screened interval is reasonably homogeneous within $200 \mathrm{ft}(61 \mathrm{~m})$ of the recharge well, water samples from the 20-, 100-, and 200-ft (6.1-, 30-, and 61-m) observation wells are considered to be representative of water everywhere on the circumference of the respective concentric cylinders. Expansion of the diameter of the cylinder is assumed to be proportional to the volume of water injected. In following discussions, chemical data on water from the observation wells are used to calculate the amount of specified constituents passing the respective concentric peripheries that circumscribe the recharge well. 
The flow system depicted by the hydraulic model is not firmly supported by water-quality data, however. Analysis of the breakthrough curve of specific conductance at the $20-\mathrm{ft}(6.1-\mathrm{m})$ well during test $\mathrm{RW} 10$ suggests that only 50 percent of the reclaimed water remains in the recharge zone, but analysis of the breakthrough curve at the $200-\mathrm{ft}$ $(61-m)$ well suggests that nearly 100 percent of the reclaimed water remains in the recharge zone. Two factors may contribute to this anomaly: (1) various processes of dispersion produce a zone of diffusion and mixing between the reclaimed and native waters, so that the reclaimed water moves through the aquifer as an irregularly advancing front $(F$. J. Pearson, Jr., and G. D. Bennett, written commun., 1972); and (2) internal flow patterns observed at the $20-\mathrm{ft}(6.1-\mathrm{m})$ observation well are complex and do not correspond to the steady-state, radially symmetric simulation (Vecchioli and others, 1974). Regardless of the exact nature of the flow pattern, the percentage of reclaimed water reaching the $200-\mathrm{ft}(61-\mathrm{m})$ periphery is unlikely to be much different from that passing the $20-\mathrm{ft}$ $(6.1 \mathrm{~m})$ periphery, because the screened interval behaves virtually as a confined zone within these distances from the recharge well.

A flow net based on a steady-state, radially symmetric, electric-analog simulation of the well-aquifer system indicates that at $200 \mathrm{ft}(61 \mathrm{~m})$ from the recharge well, 70 percent of the flow is within the screened interval (Vecchioli and others, 1974$)$. Thus, at a $20-\mathrm{ft}(6.1-\mathrm{m})$ radius, the flow in the screened interval should be no less than 70 percent.

To define the movement of reclaimed water through the aquifer, chloride concentrations of water samples were used to measure the extent of mixing between native and reclaimed waters. To do this, a mixing coefficient $\left(V_{I}\right)$ was calculated (F. J. Pearson, Jr., and G. D. Bennett, written commun., 1971) and is defined as:

where

$$
V_{I}=\frac{C_{s}-C_{n}}{C_{i}-C_{n}}
$$

$V_{I}=$ in essence, the ratio of the concentration of a given constituent in the water sample to the concentration of that constituent in the reclaimed water

$C_{s}=$ the concentration of that constituent in the water sample

$C_{n}=$ the concentration of that constituent in native water, and

$C_{i}=$ the concentration of that constituent in injected water.

The $V_{I}$ values calculated for other constituents in the water sample indicate their reactivity compared with that of $\mathrm{Cl}^{-}$(chloride). A $V_{I}$ value greater than that for $\left(V_{I}\right)_{\mathrm{Cr}^{-}}$(see footnote 1) indicates a concentration greater than can be explained by a simple-mixing model (equation 1 ), and a $V_{I}$ less than that for $\left(V_{I}\right)_{\mathrm{Cl}^{-}}$indicates a concentration less than can be explained by the model.

\section{IRON-MOBILIZATION REACTIONS}

Although iron concentrations of reclaimed water and native water in the recharge zone are less than $0.5 \mathrm{mg} / 1$ (table 3), the iron concentration of samples taken during test RW13 from the 20-, 100-, and 200-ft $(6.1-, 30-, 61-\mathrm{m})$ observation wells at times approached $3 \mathrm{mg} / \mathrm{l}$. Most of the earlier tests were too short for reclaimed water to reach the $100-$ and $200-\mathrm{ft}(30-$ and $61-\mathrm{m})$ wells, but increased iron concentrations were observed at the $20-\mathrm{ft}(6.1-\mathrm{m})$ well in several tests (table 6). Iron mass-balance data indicate that

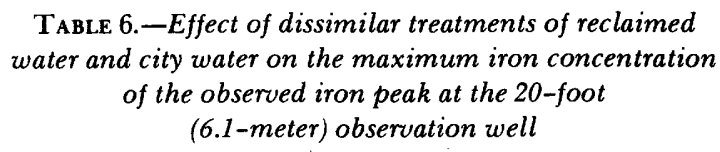

\begin{tabular}{lcc}
\hline $\begin{array}{l}\text { Recharge } \\
\text { test }\end{array}$ & Treatment & $\begin{array}{c}\text { Maximum iron } \\
\text { concentration } \\
(\mathbf{m g} / \mathbf{l})\end{array}$ \\
\hline
\end{tabular}

RW10, part I Carbon filters bypassed; high COD $\ldots \ldots \ldots \ldots \ldots \ldots \ldots \ldots \ldots \ldots, 3.05$

RW10, part II Unchlorinated $\ldots \ldots \ldots \ldots \ldots \ldots \ldots \ldots \ldots, 1.20$

RW11 Dechlorinated using sodium

RW12 Raised pH to 8 using sodium hydroxide $\ldots \ldots \ldots \ldots \ldots \ldots \ldots \ldots \ldots . .37$

RW13 Normal treatment (see section

"Bay Park sewage-treatment plant and demonstration tertiary-treatment plant") $\ldots \ldots \ldots \ldots \ldots .2 .88$

CW6 $\ldots \ldots$ do $\ldots \ldots \ldots \ldots \ldots$. $\begin{array}{r}\text { No change from } \\ \text { native water. }\end{array}$

iron-bearing minerals must be dissolving and that pyrite and marcasite $\left(\mathrm{FeS}_{2}\right)$ are the only source of iron present in sufficient quantity to have caused the increased iron concentration (Ragone and others, 1973). Within a 20-ft $(6.1-\mathrm{m})$ radius of the recharge well, dissolved oxygen in the reclaimed water oxidizes $\mathrm{FeS}_{2}$ and releases $\mathrm{Fe}^{+2}$ to solution. However, the fact that the dissolved iron content of water passing cylindrical sections of radii 100 and $200 \mathrm{ft}$ $(30$ and $61 \mathrm{~m}$ ) from the recharge well is greater than that of water passing a cylindrical section of radius $20 \mathrm{ft}(6.1 \mathrm{~m})$ from the recharge well, even though dissolved oxygen does not reach the $20-\mathrm{ft}(6.1-\mathrm{m})$ radius, indicates that other factors must be controlling the addition of iron to the system.

Changes in iron concentration and $\mathrm{pH}$ as functions of the fraction of reclaimed water in water samples at the 20-,

1. This term distinguishes the $V_{I}$ of chloride from the $V_{I}$ of other constituents. 
$100-$, and $200-\mathrm{ft}(6.1-, 30-$, and $61-\mathrm{m})$ observation wells are given in figures 5 and 6 . With the arrival of reclaimed water at the observation wells, iron increases and $\mathrm{pH}$ decreases simultaneously. At the 20 - and $100-\mathrm{ft}(6.1-$ and $30-\mathrm{m}$ ) wells, iron concentration reaches a maximum of nearly $3 \mathrm{mg} / \mathrm{l}$ at $\left(V_{l}\right)_{\mathrm{Cl}^{-}}$values of 0.4 and 0.5 , respectively, then decreases as $\left(V_{l}\right)_{\mathrm{Cl}^{-}}$approaches 1 . This suggests that the increase in iron concentration occurs in the reclaimedwater front as the reclaimed water displaces native water.

Native water at a radius of $200 \mathrm{ft}(61 \mathrm{~m})$ was not completely displaced by reclaimed water because the test was not long enough (fig. 6). Whether the $3-\mathrm{mg} / \mathrm{l}$ iron concentration observed at the end of the test is the maximum concentration, or whether it would have increased with continued recharge, is not known.

The $\mathrm{pH}$ of samples from the 20 - and $100-\mathrm{ft}(6.1$ - and 30 $\mathrm{m})$ wells decreased with the arrival of reclaimed water, reached a minimum at about the same time that iron concentration reached a maximum, and then increased (figs. 5 and 6). At the $200-\mathrm{ft}(61-\mathrm{m})$ well (fig. 6), the $\mathrm{pH}$ decreased until the end of the test. The minimum $\mathrm{pH}$ was successively lower at the 20-, 100-, and 200-ft $(6.1-, 30-$, and $61-\mathrm{m}$ ) wells.

Iron-mass balance calculations showed that the increased amount of iron in water passing a cylindrical section of radius $20 \mathrm{ft}(6.1 \mathrm{~m})$ from the recharge well could not be accounted for by iron in the reclaimed water (Ragone and others, 1973). Iron content of the mixed water passing cylindrical sections of greater radii continues to increase-going from $6.4 \times 10^{7} \mathrm{mg}$ at $20 \mathrm{ft}(6.1 \mathrm{~m})$ to $20.1 \mathrm{x}$ $10^{7} \mathrm{mg}$ at $100 \mathrm{ft}(30 \mathrm{~m})$ and to (see footnote 2$) 18.5 \times 10^{7} \mathrm{mg}$ at $200 \mathrm{ft}(61 \mathrm{~m})$; this increase indicates that the source of dissolved iron is in the aquifer. These values represent the areas under those parts of the iron-concentration curves in figures 5 and 6 that exceed native-water concentrations. Because pyrite and marcasite are the only known iron minerals in the recharge zone, the increase in iron concentration within $20 \mathrm{ft}(6.1 \mathrm{~m})$ of the recharge well was probably caused by oxidation of these minerals by dissolved oxygen in the reclaimed water (Ragone and others, 1973). DO concentration of the first $2 \mathrm{Mgal}(7.6 \mathrm{mil} \mathrm{l})$ of reclaimed water injected during test $R W 13$ was $5 \mathrm{mg} / 1$. On the basis of this value, the concentration of $\mathrm{Fe}^{+2}$ produced by oxidation reaction

$\mathrm{FeS}_{2}+7 / 2 \mathrm{O}_{2}+\mathrm{H}_{2} \mathrm{O}=\mathrm{Fe}^{+2}+2 \mathrm{SO}_{4}^{-2}+2 \mathrm{H}+$

2. This is a minimum value, as reclaimed water did not completely displace native water at the radius of $200 \mathrm{ft}(61 \mathrm{~m})$.
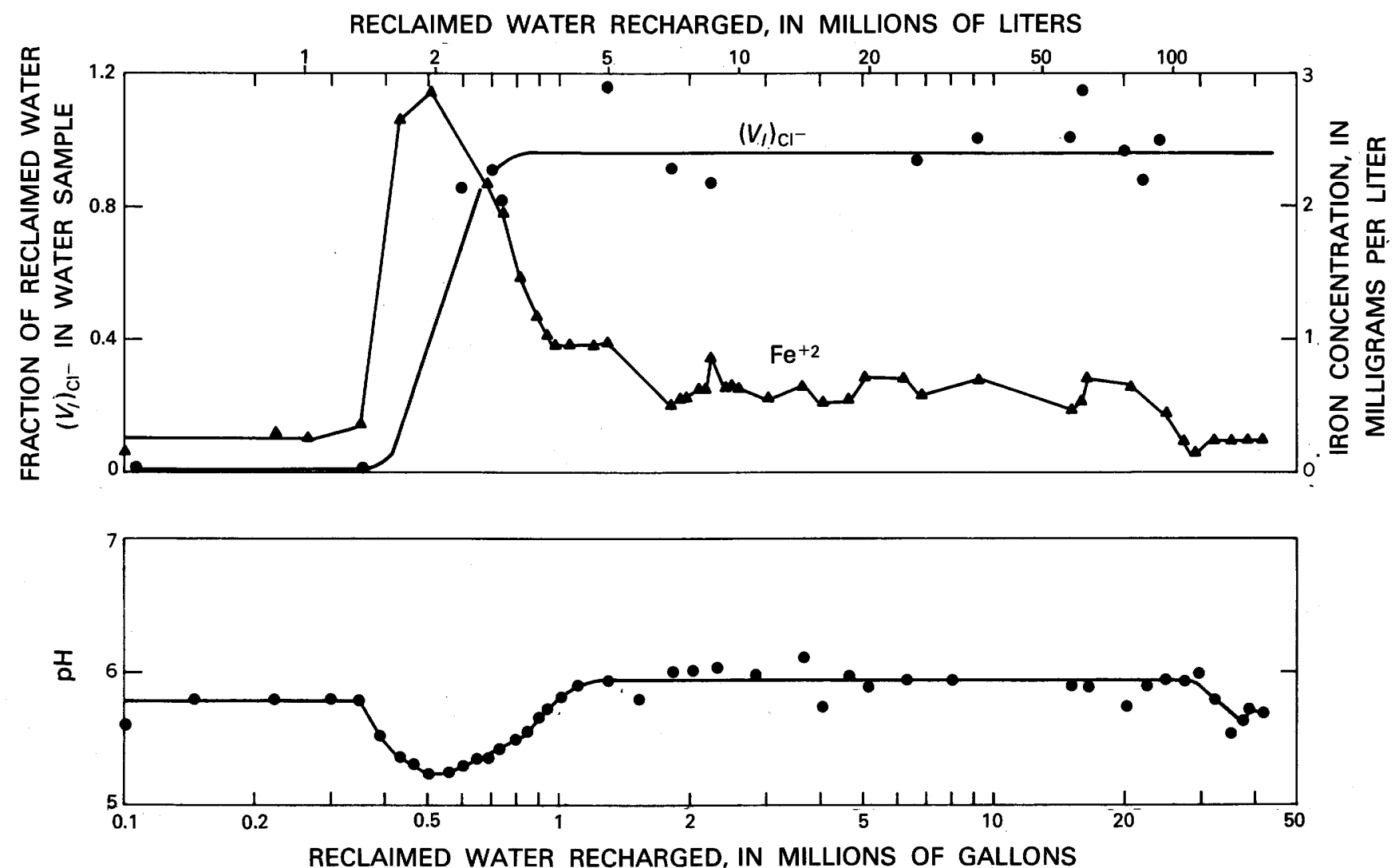

Figure 5.-Changes in iron concentration and $\mathrm{pH}$ as a function of the fraction of reclaimed water $\left(V_{l}\right)_{\mathrm{Cl}^{-}}$at the 20 -toot $(6.1-\mathrm{meter})$ observation well during recharge. 

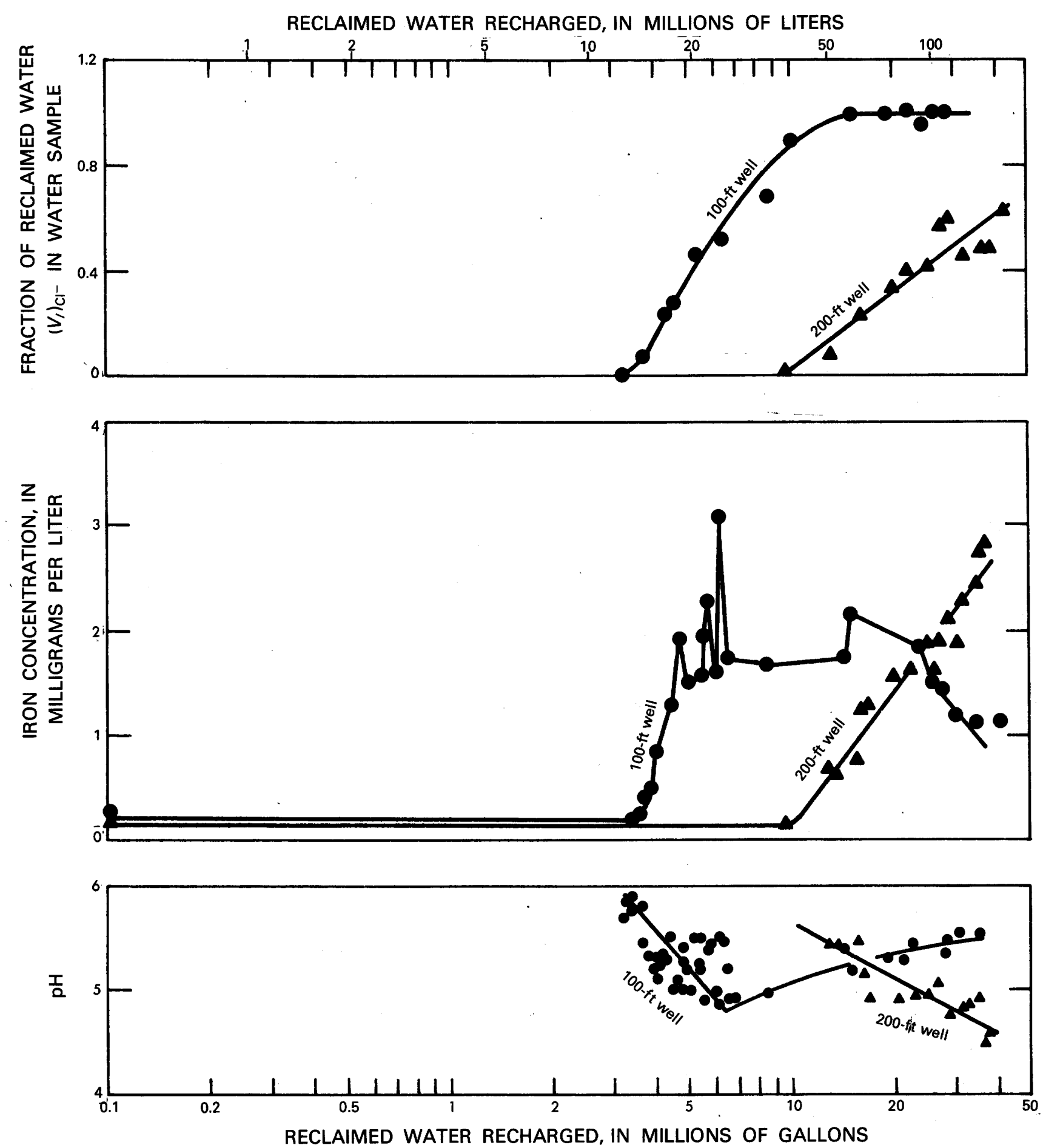

FIGURE 6.-Changes in iron concentration and $\mathrm{pH}$ as a function of the fraction of reclaimed water $\left(V_{l}\right)_{\mathrm{C}^{-}}$at the 100 -foot and 200-foot (30and 61-meter) observation wells during recharge.

is $2.5 \mathrm{mg} / \mathrm{l}$. This calculation agrees well with the observed value of $2.9 \mathrm{mg} / \mathrm{l}$. A similar correlation between DO concentration and iron concentration was observed during test RW10 (Ragone and others, 1973). However, water reaching the $20-\mathrm{ft}(6.1-\mathrm{m})$ well had no detectable DO concentration; therefore oxidation of $\mathrm{FeS}_{2}$ by $\mathrm{DO}$ in the reclaimed water cannot explain the increase in iron observed at the $100-$ and $200-\mathrm{ft}(30-$ and $61-\mathrm{m})$ wells. It may be that other factors, such as organic complexing and auto-oxidation of divalent iron by $\mathrm{Fe}^{+3}$ (trivalent iron), contribute to the continued mobilization of iron.

\section{CATION-EXCHANGE REACTIONS}

Higher concentrations of alkali and alkaline earth 


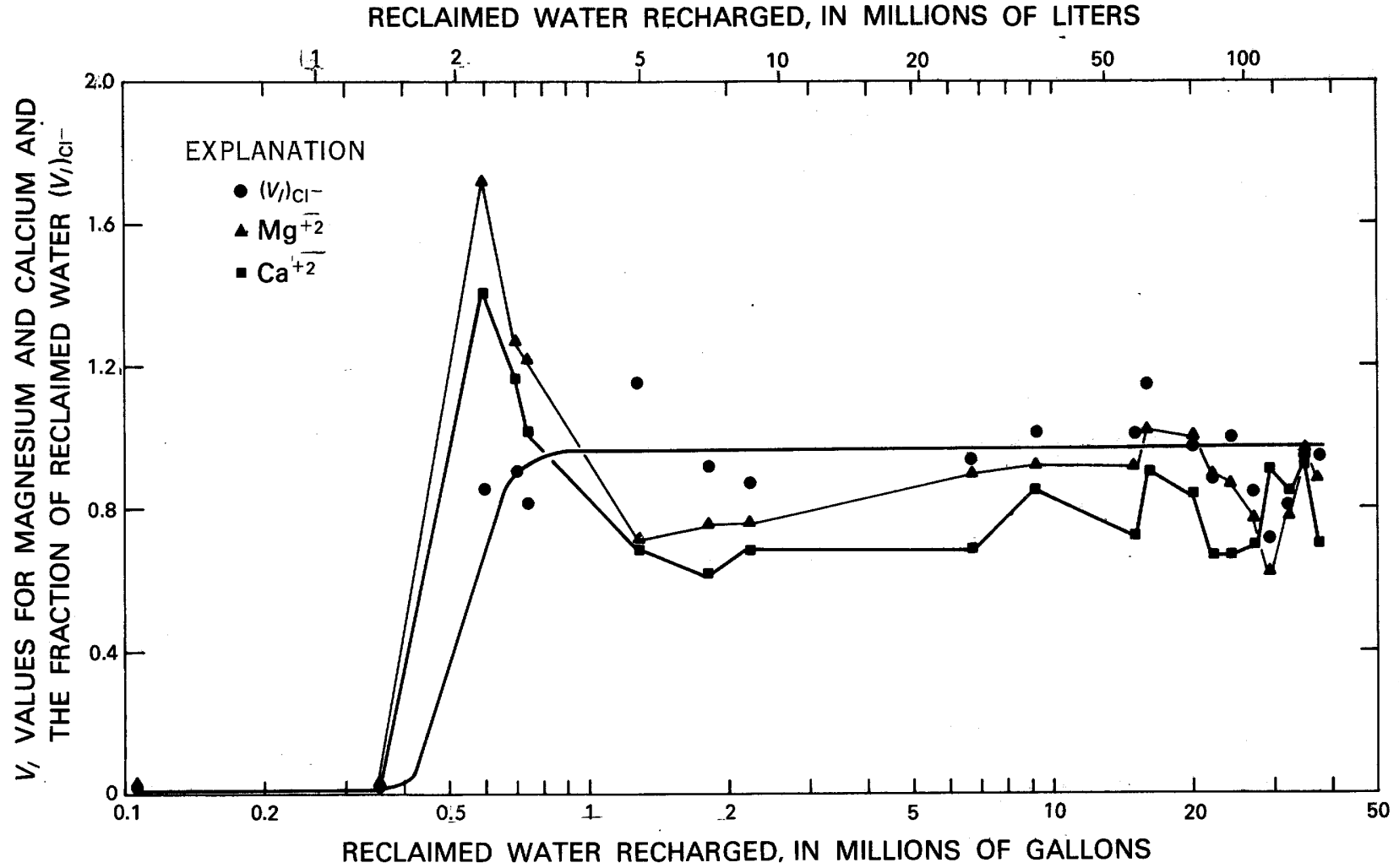

FIGURE 7.-Changes in $V_{I}$ values for magnesium and calcium as a function of the fraction of reclaimed water $\left(V_{I}\right)_{\mathrm{Cl}^{-}}$at the 20 -foot (6.1meter) observation well during recharge.

metals and $\mathrm{NH}_{4}^{+}$(ammonium) in the reclaimed water than in native water, and the presence of clay minerals in the recharge zone, seem to cause some cation exchange during recharge; that is, a loss of $\mathrm{NH}_{4}^{+}$and $\mathrm{K}^{+}$(potassium) from solution seems to be balanced by an increase in $\mathrm{H}^{+}$(hydrogen ion).

$V_{l}$ curves for $\mathrm{Mg}^{+_{2}}$ (magnesium) and $\mathrm{Ca}^{+}{ }_{2}$ (calcium) at the $20-\mathrm{ft}(6.1-\mathrm{m})$ well do not have the usual S-shape that the $\left(V_{l}\right)_{\mathrm{Cl}^{-}}$curve has (fig. 7). During the period when reclaimed water is displacing native water from the vicinity of this well, that is, when $\left(V_{I}\right)_{\mathrm{Cr}}$ is greater than zero but less than 1 , concentrations of $\mathrm{Mg}^{+2}$ and $\mathrm{Ca}^{+2}$ exceed those predicted by the simplified aquifer-flow model described earlier. With continued injection, $V_{I}$ values for $\mathrm{Mg}^{+_{2}}$ and $\mathrm{Ca}^{+{ }_{2}}$ decrease below that of $\left(V_{I}\right)_{\mathrm{Cr}^{-}}$, then approach the $\left(V_{1}\right)_{\mathrm{Cl}^{-}}$curve near the end of the test (fig. 7).

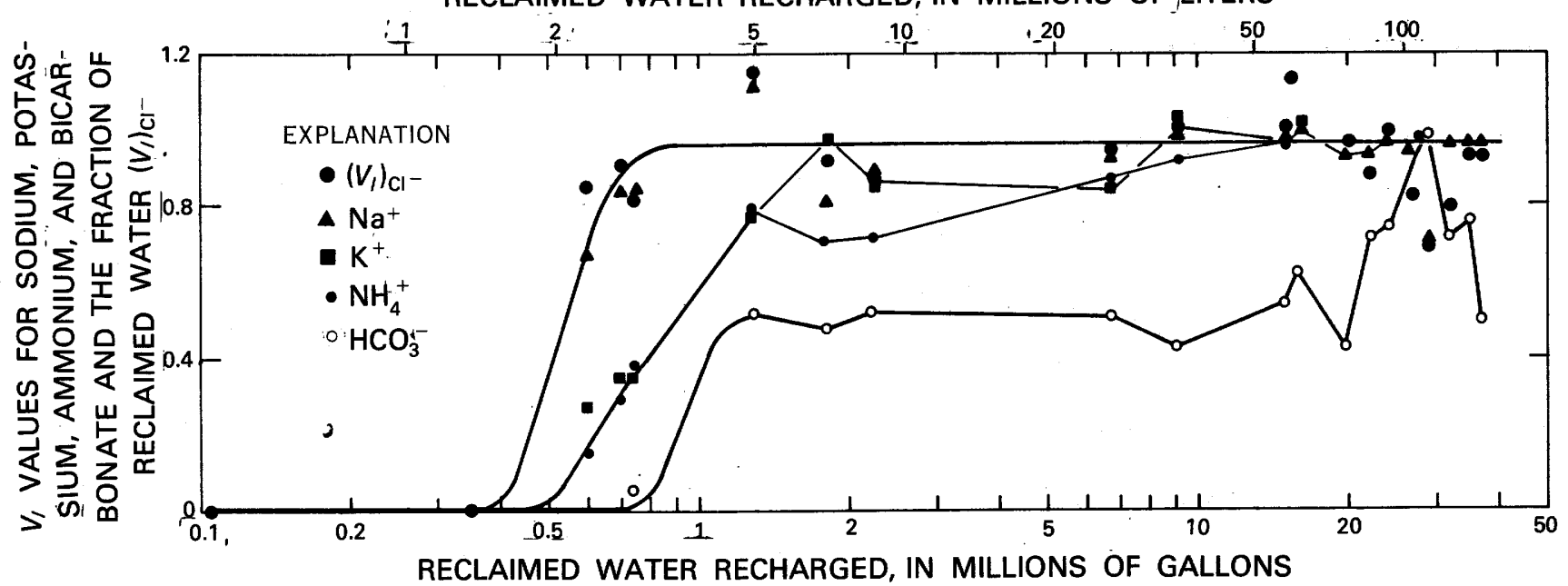

FIGURE 8. - Changes in $V_{l}$ values for sodium, potassium, ammonium, and bicarbonate as a function of the fraction of reclaimed water $\left(V_{l}\right)_{\mathrm{Cl}^{-}}$at the 20 -foot (6.1-meter) observation well during recharge. 
The increase in the concentration of $\mathrm{Mg}^{+2}$ and $\mathrm{Ca}^{+2}$ is 11 $\mathrm{mg} / 1$ and $24 \mathrm{mg} / \mathrm{l}$, respectively, as compared with the average dissolved-solids concentration of $463 \mathrm{mg} / 1$ of reclaimed water, and represents only a small percentage of the dissolved-solids load.

$V_{I}$ values for $\mathrm{Na}^{+}$(sodium), $\mathrm{K}^{+}, \mathrm{NH}_{4}^{+}$, and $\mathrm{HCO}_{3}^{-}$ (bicarbonate), on the other hand, remain below that of $\left(V_{l}\right)_{\mathrm{Ci}^{-}}$(fig. 8), which indicates that concentrations of these constituents of the water at the $20-\mathrm{ft}(6.1-\mathrm{m})$ well are less than predicted by the simplified aquifer-flow model. The $V_{l}$ curve for $\mathrm{HCO}_{3}{ }^{-}$indicates that this constituent has the lowest $V_{I}$ of that group. The $\mathrm{HCO}_{3}^{-}$curve indicates changes in $\mathrm{H}^{+}$concentration in solution (Faust and Vecchioli, 1974) and, in calculations that follow, the amount of $\mathrm{HCO}_{3}^{-}$lost from solution is equated to the amount of $\mathrm{H}^{+}$added to solution.

The extent to which the noted excesses of $\mathrm{Ca}^{+}, \mathrm{Mg}^{+}$, and $\mathrm{H}^{+}$and the deficits of $\mathrm{NH}_{4}^{+}$and $\mathrm{K}^{+}$are caused by cation exchange was determined by comparing the concentrations of cations added to the reclaimed water with the concentrations of those removed from the water. To do this, actual concentrations of the constituents of the water samples were compared with concentrations that were calculated from the simplified aquifer-flow model (table 7). The calculated concentrations were determined by solving equation $I$ for $C_{s}$ and using $\left(V_{I}\right)_{\mathrm{Cl}^{-}}$values for $V_{I}$ to obtain

$$
\left(C_{s}\right)=\left[\left(V_{l}\right)_{\mathrm{Cl}^{-1}}\right]\left[C_{i} C_{n}\right]+C_{n} .
$$

After 0.6 Mgal (2.3 mil l) recharge the volume at which the $V_{I}$ for $\mathrm{Ca}^{+2}$ and $\mathrm{Mg}^{+2}$ is greatest (fig. 7), $1.32 \mathrm{meq} / \mathrm{l}$ (milliequivalent per liter) more cations have been added to solution than have been removed (table 7). This value is too large to result from experimental or sampling error and suggests that other reactions besides cation exchange may be occurring as well. $\mathrm{As} \mathrm{Ca}^{+2}$ and $\mathrm{Mg}^{+2}$ are the only cations whose concentrations significantly increase, they must be entering solution through some mechanism that has not been explained by available data. Deleting these cations and $\mathrm{Na}^{+}$(see footnote 3 ) from the cation balance produces a good agreement between added and subtracted constituents- $\mathrm{NH}_{4}^{+}$and $\mathrm{K}^{+}$account for a $0.94 \mathrm{meq} / 1$ loss from solution, and $\mathrm{H}^{+}$accounts for a $0.91 \mathrm{meq} / 1$ gain to solution.

The balance for added and substracted cations at 0.7 Mgal (2.6 mil l) and at $0.74 \mathrm{Mgal}(2.8 \mathrm{mil} \mathrm{l})$ recharge is similar to that for $0.6 \mathrm{Mgal}$ (2.3 mil 1) recharge (table 7). Again, deleting $\mathrm{Ca}^{+2}, \mathrm{Mg}^{+2}$, and $\mathrm{Na}^{+}$from the cation balance produces excellent agreement between added and

\footnotetext{
3. Sodium ion was not included in the mass bal ance because the difference between observed and calculated concentrations is relatively small and varies erratically from a positive to negative deviation. This suggests analytical errors rather than real changes.
}

subtracted cations; the difference is 0.01 at $0.7 \mathrm{Mgal}$ (2.6 mil l) and 0.00 at $0.74 \mathrm{Mgal}$ ( $2.8 \mathrm{mil} \mathrm{l}$ ). Although the differences between observed and calculated concentrations of $\mathrm{Ca}^{+2}$ and $\mathrm{Mg}^{+2}$ decrease substantially as recharge increases, differences between observed and calculated concentrations of $\mathrm{K}^{+}, \mathrm{NH}_{4}^{+}$, and $\mathrm{HCO}_{3}{ }^{-}$remain relatively large. This supports the earlier suggestion that cation exchange does not explain the large net increases in concentrations of $\mathrm{Ca}^{+2}$ and $\mathrm{Mg}^{+2}$ as reclaimed water displaces native water from the vicinity of the $20-\mathrm{ft}(6.1-\mathrm{m})$ well. The increase in $\mathrm{Ca}^{+2}$ and $\mathrm{Mg}^{+2}$ cannot be explained by dissolution of carbonate minerals because none were found during mineralogical investigations of cores from the recharge well. The large net increases may, however, result from the dislodgment of calcium and magnesium salts that were entrapped near the recharge well in earlier tests, that is, salts that were not completely removed during well redevelopment.

The balance of the cations $\mathrm{NH}_{4}^{+}, \mathrm{K}^{+}$, and $\mathrm{H}^{+}$observed for samples collected through $0.74 \mathrm{Mgal}(2.8 \mathrm{mil} \mathrm{l})$ recharge is poor for samples collected after $1.3 \mathrm{Mgal}(4.9$ mil 1) recharge (table 7), which suggests that cationexchange reaction involving these constituents has stopped.

Of all the constituents determined at the 100-ft (30-m) well, only $\mathrm{Mg}^{+2}$ shows an excess in concentration (figs. 9 and 10).

Cation-balance calculations indicate that relationships observed at the $100-\mathrm{ft}(30-\mathrm{m})$ well (table 8$)$ are similar to those described for the $20-\mathrm{ft}(6.1-\mathrm{m})$ well-the increase in $\mathrm{H}^{+}$is balanced by a decrease in $\mathrm{NH}_{4}^{+}$and $\mathrm{K}^{+}$through 15 $\mathrm{Mgal}$ (57 mil l) of recharge. After this amount of recharge, poor correlation suggests cessation of cation exchange.

As at the $100-\mathrm{ft}(30-\mathrm{m})$ well, only $\mathrm{Mg}^{+2}$ concentration exceeds the concentration calculated from the simplified aquifer flow model at the $200-\mathrm{ft}(61-\mathrm{m})$ well (figs. 11 and 12). The $\mathrm{HCO}_{3}^{-}$values are low and often zero; thus it is not known whether the decrease in $\mathrm{HCO}_{3}^{-}$concentration equals an increase in $\mathrm{H}^{+}$concentration, and, consequently, the mass-balance calculations cannot be made. However, the relatively large decrease in concentrations of $\mathrm{K}^{+}$and $\mathrm{NH}_{4}^{+}$(table 9) suggest that $\mathrm{NH}_{4}^{+}$and $\mathrm{K}^{+}$may also be involved in cation exchange at the $200-\mathrm{ft}(61-\mathrm{m})$ well.

\section{MOVEMENT OF POLLUTANT-INDICATOR CONSTITUENTS THROUGH THE AQUIFER DURING RECHARGE}

Nitrogen, phosphorus, and organic constituents of water are often used as pollution indicators; that is, these constituents are present in chemical and microbiological reactions that degrade water quality. In addition, nitrate has been linked to methemoglobinemia in infants (Walton, 1951).

Tertiary treatment at Bay Park removes 98 percent of the phosphorus from secondary sewage (Vecchioli and others, 
TABLE 7.-Differences between observed and calculated concentrations of calcium,

magnesium, sodium, potassium, ammonium, and hydrogen ions in water

from the 20-foot (6.1-meter) observation well, in milliequivalents per liter

\begin{tabular}{|c|c|c|c|c|c|c|c|c|c|c|c|c|c|c|}
\hline \multirow{3}{*}{ Constituents } & \multicolumn{14}{|c|}{ Volume of water injected, in millions of gallons } \\
\hline & \multicolumn{2}{|c|}{0.60} & \multicolumn{2}{|c|}{0.70} & \multicolumn{2}{|c|}{0.74} & \multicolumn{2}{|c|}{1.3} & \multicolumn{2}{|c|}{2.2} & \multicolumn{2}{|c|}{9.1} & \multicolumn{2}{|c|}{22} \\
\hline & Difference & $\begin{array}{l}\text { Percentage } \\
\text { difference }\end{array}$ & Difference & $\begin{array}{l}\text { Percentage } \\
\text { difference }\end{array}$ & Difference & $\begin{array}{l}\text { Percentage } \\
\text { difference }\end{array}$ & Difference & $\begin{array}{l}\text { Percentage } \\
\text { difference }\end{array}$ & Difference & $\begin{array}{l}\text { Percentage } \\
\text { difference }\end{array}$ & Difference & $\begin{array}{l}\text { Percentage } \\
\text { difference }\end{array}$ & Difference & $\begin{array}{l}\text { Percentage } \\
\text { difference }\end{array}$ \\
\hline $\mathrm{Ca}^{+t_{2}} \ldots \ldots \ldots$ & $\ldots+0.66$ & +68 & +0.24 & +25 & +0.12 & +13 & -0.20 & -29 & -0.21 & -30 & -0.10 & -11 & -0.25 & -33 \\
\hline $\mathrm{Mg}^{+2} \ldots \ldots \ldots \ldots$ & $\ldots+.58$ & +83 & +.20 & +31 & +.16 & +25 & -.15 & -30 & -.03 & -8 & -.02 & -4 & -.03 & -7 \\
\hline $\mathrm{Na}^{+} \ldots \ldots \ldots \ldots$ & $\ldots+.11$ & +4 & -.19 & -6 & -.30 & -9 & +.42 & +12 & -.22 & -7 & +.11 & +3 & -.05 & -2 \\
\hline $\mathrm{K}^{+} \quad \ldots \ldots \ldots \ldots$ & $\ldots-.11$ & -69 & -.16 & -76 & -.17 & -77 & -.05 & -18 & -.03 & -10 & +.03 & +9 & +.02 & +7 \\
\hline $\mathrm{NH}_{4}{ }^{+} \ldots \ldots \ldots \ldots$ & $\ldots-.83$ & -110 & -1.00 & -92 & -.95 & -82 & -.29 & -18 & -.42 & -28 & -.07 & -5 & 0 & 0 \\
\hline $\mathrm{H}^{+}$(see footnote 1 ) & $\ldots+.91$ & +150 & +1.15 & +144 & +1.12 & +130 & +.57 & +48 & +.58 & +49 & +.34 & +49 & +.16 & +21 \\
\hline Gain or loss ${ }^{2}$ & $\ldots+1.32$ & $\ldots \ldots$ & +.24 & $\ldots$ & -.02 & $\ldots$ & +.30 & $\ldots$ & -.33 & & +.29 & $\ldots$ & -.15 & $\ldots$ \\
\hline
\end{tabular}

${ }^{1} \mathrm{H}^{+}$gained by solution assumed equal to $\mathrm{HCO}_{3}{ }^{-}$lost from solution

2 Plus sign indicates that cations have been added to solution; minus sign indicates that cations have been removed. 


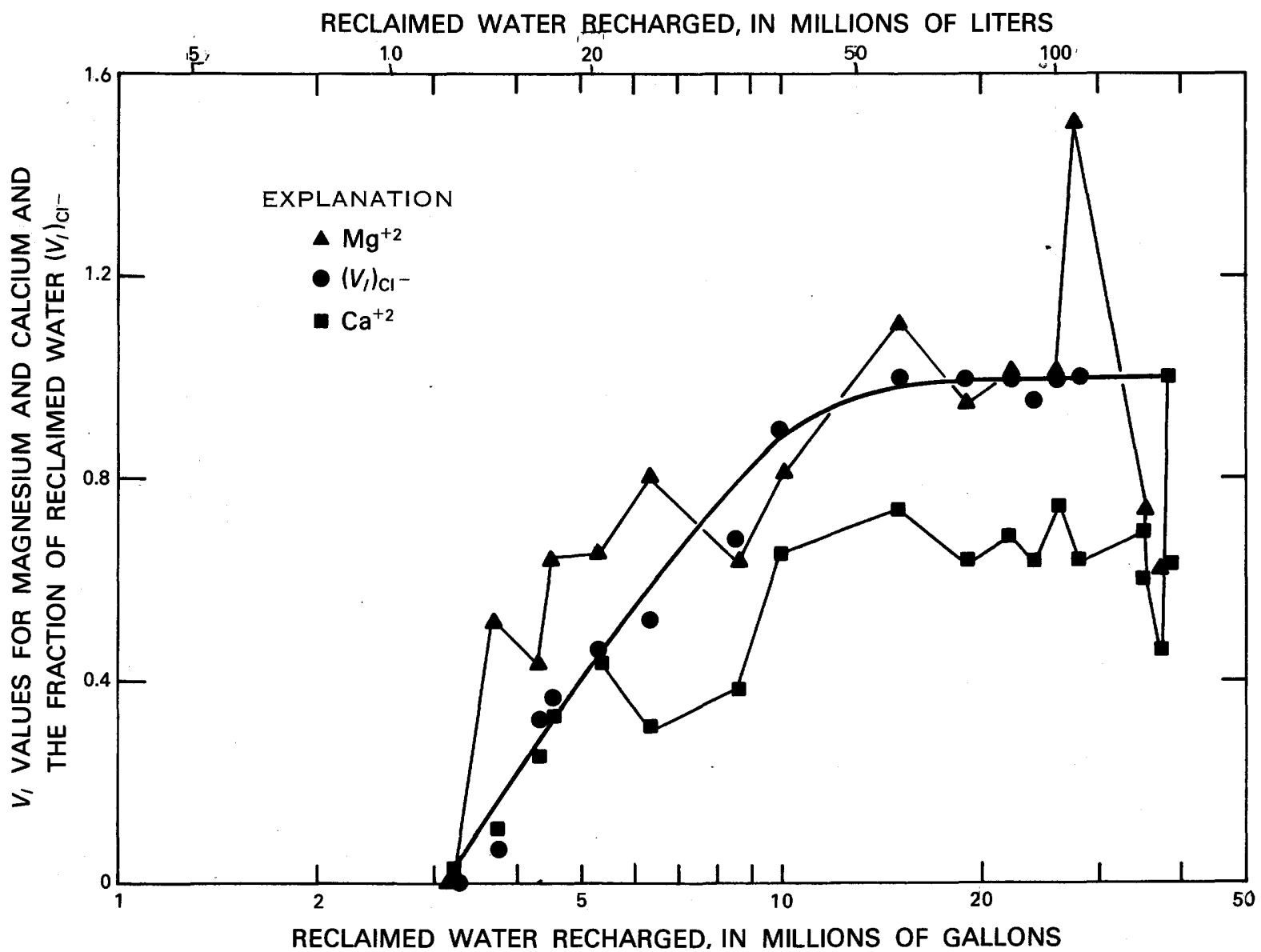

FIGURE 9.-Changes in $V_{I}$ values for calcium and magnesium as a function of the fraction of reclaimed water $\left(V_{l}\right)_{(\mathrm{I}]}$-at the $100-$ foot (30-meter) observation well during recharge.

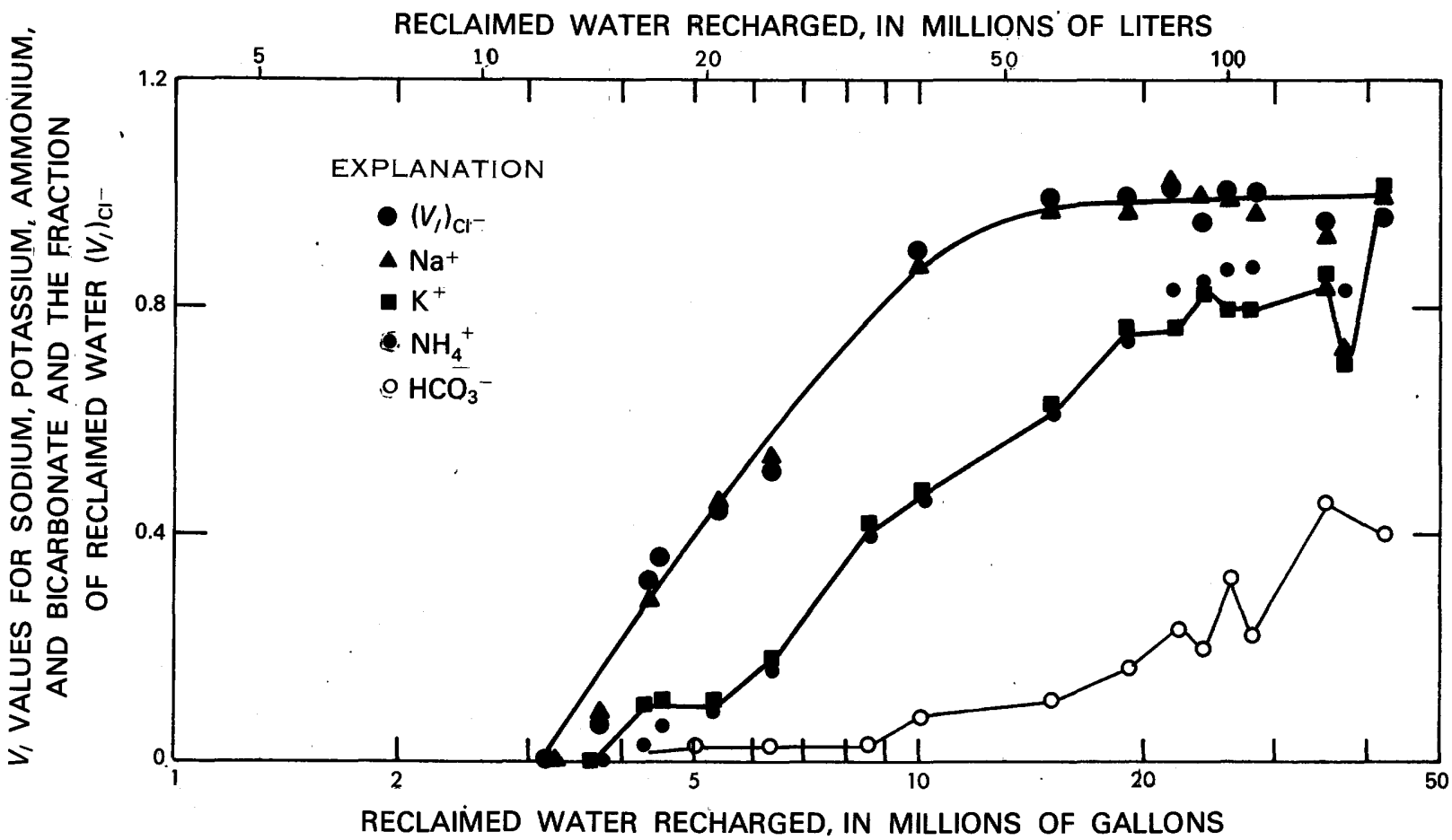

FIGURE 10.-Changes in $V_{I}$ values for sodium, potassium, ammonium, and bicarbonate as a function of the fraction of reclaimed water $\left(V_{l}\right)_{\mathrm{Cl}^{-}}$at the 100-foot (30-meter) observation well during recharge. 
TABLE 8.-Differences between observed and calculated concentrations of calcium, magnesium, sodium, potassium, ammonium, and hydrogen ions in water from the

100-foot (30-meter) observation well

\begin{tabular}{|c|c|c|c|c|c|c|c|c|c|c|c|c|}
\hline \multirow{3}{*}{ Cinstituents } & \multicolumn{12}{|c|}{ Volume of water injected, in millions of gallons } \\
\hline & \multicolumn{2}{|c|}{3.7} & \multicolumn{2}{|c|}{4.3} & \multicolumn{2}{|c|}{5.3} & \multicolumn{2}{|c|}{6.3} & \multicolumn{2}{|c|}{8.5} & \multicolumn{2}{|c|}{10} \\
\hline & Difference & $\begin{array}{l}\text { Percentage } \\
\text { difference }\end{array}$ & Difference & $\begin{array}{l}\text { Percentage } \\
\text { difference }\end{array}$ & Difference & $\begin{array}{l}\text { Percentage } \\
\text { difference }\end{array}$ & Difference & $\begin{array}{l}\text { Percentage } \\
\text { difference }\end{array}$ & Difference & $\begin{array}{l}\text { Percentage } \\
\text { difference }\end{array}$ & Difference & $\begin{array}{l}\text { Percentage } \\
\text { difference }\end{array}$ \\
\hline $\mathrm{Ca}^{+2} \quad \ldots \ldots \ldots$ & $\ldots+0.03$ & +24 & +0.03 & +13 & +0.01 & +3 & -0.17 & -45 & -0.38 & -64 & -0.21 & -28 \\
\hline $\mathrm{Mg}^{+_{2}} \ldots \ldots \ldots$ & $\ldots+.02$ & +29 & +.13 & +.63 & +.11 & +40 & +.13 & +39 & -.08 & -19 & -.04 & -9 \\
\hline $\mathrm{Na}^{+} \ldots \ldots \ldots$ & $\ldots-.11$ & -29 & +.07 & +8 & -.05 & -3 & -.10 & -6 & -.60 & -24 & -.14 & -5 \\
\hline $\mathrm{K}^{+} \ldots \ldots \ldots$ & $\ldots-.02$ & -67 & -.03 & -46 & -.10 & -100 & -.12 & -86 & -.13 & -58 & -.14 & -70 \\
\hline $\mathrm{NH}_{4}{ }^{+} \ldots \ldots \ldots$ & $\ldots-.12$ & -171 & -.31 & -198 & -.59 & -130 & -.57 & -101 & -.59 & -62 & -.63 & -57 \\
\hline $\mathrm{H}^{+}$(see footnote 1 ) & $\ldots+.10$ & +67 & +.37 & +140 & +.40 & +174 & +.48 & +178 & +.69 & +184 & +.71 & +163 \\
\hline Gain or loss² & $\ldots-.10$ & $\ldots$ & +.26 & $\ldots$ & -.22 & 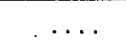 & -.35 & & -1.09 & & -.45 & \\
\hline
\end{tabular}

\begin{tabular}{|c|c|c|c|c|c|c|c|c|c|c|}
\hline \multirow{3}{*}{ Constituents } & \multicolumn{10}{|c|}{ Volume of water injected, in million of gallons-Continued } \\
\hline & \multicolumn{2}{|c|}{15} & \multicolumn{2}{|c|}{19} & \multicolumn{2}{|c|}{26} & \multicolumn{2}{|c|}{35} & \multicolumn{2}{|c|}{42} \\
\hline & Difference & $\begin{array}{l}\text { Percentage } \\
\text { difference }\end{array}$ & Difference & $\begin{array}{l}\text { Percentage } \\
\text { difference }\end{array}$ & Difference & $\begin{array}{l}\text { Percentage } \\
\text { difference }\end{array}$ & Difference & $\begin{array}{l}\text { Percentage } \\
\text { difference }\end{array}$ & Difference & $\begin{array}{l}\text { Percentage } \\
\text { difference }\end{array}$ \\
\hline $\begin{array}{l}\mathrm{Ca}^{+2}{ }_{2} \ldots \ldots \ldots \ldots \\
\mathrm{Mg}^{+2} \ldots \ldots \ldots \ldots \ldots \\
\mathrm{Na}^{+} \ldots \ldots \ldots \ldots \ldots \\
\mathrm{K}^{+} \ldots \ldots \ldots \ldots \ldots \\
\mathrm{NH}_{4}^{+} \ldots \ldots \ldots \ldots \\
\mathrm{H}^{+} \text {(see footnote } 1 \text { ) }\end{array}$ & $\begin{array}{l}-0.23 \\
-.04 \\
-.27 \\
-.11 \\
-.63 \\
+.79\end{array}$ & $\begin{array}{l}-28 \\
-\quad 8 \\
-\quad 8 \\
-43 \\
-48 \\
+160\end{array}$ & $\begin{array}{l}-0.33 \\
-.03 \\
-.27 \\
-.04 \\
-.41 \\
+.74\end{array}$ & $\begin{array}{l}-43 \\
-\quad 6 \\
-\quad 8 \\
-15 \\
-29 \\
+144\end{array}$ & $\begin{array}{l}-0.23 \\
-.01 \\
-.18 \\
-.06 \\
-.20 \\
+.63\end{array}$ & $\begin{array}{l}-28 \\
-\quad 2 \\
-\quad 5 \\
-\quad 8 \\
-13 \\
+110\end{array}$ & $\begin{array}{l}-0.40 \\
-.26 \\
-1.04 \\
-.08 \\
-.06 \\
+.44\end{array}$ & $\begin{array}{l}-47 \\
-42 \\
-22 \\
-25 \\
-\quad 4 \\
+73\end{array}$ & $\begin{array}{l}-0.47 \\
-.10 \\
+.27 \\
+.30 \\
-.06 \\
+.52\end{array}$ & $\begin{array}{r}-43 \\
-16 \\
+\quad 7 \\
+\quad 65 \\
-\quad 4 \\
+\quad 93\end{array}$ \\
\hline Gain or loss ${ }^{2}$ & -.49 & $\ldots$ & -.34 & $\ldots$ & -.05 & $\ldots$ & -1.40 & $\ldots$. & +.46 & $\ldots$ \\
\hline
\end{tabular}

${ }^{1} \mathrm{H}^{+}$gained by solution assumed equal to $\mathrm{HCO}_{3}{ }^{-}$lost from solution

2 Plus sign indicates that cations have been added to solution; minus sign indicates that cations have been removed. 


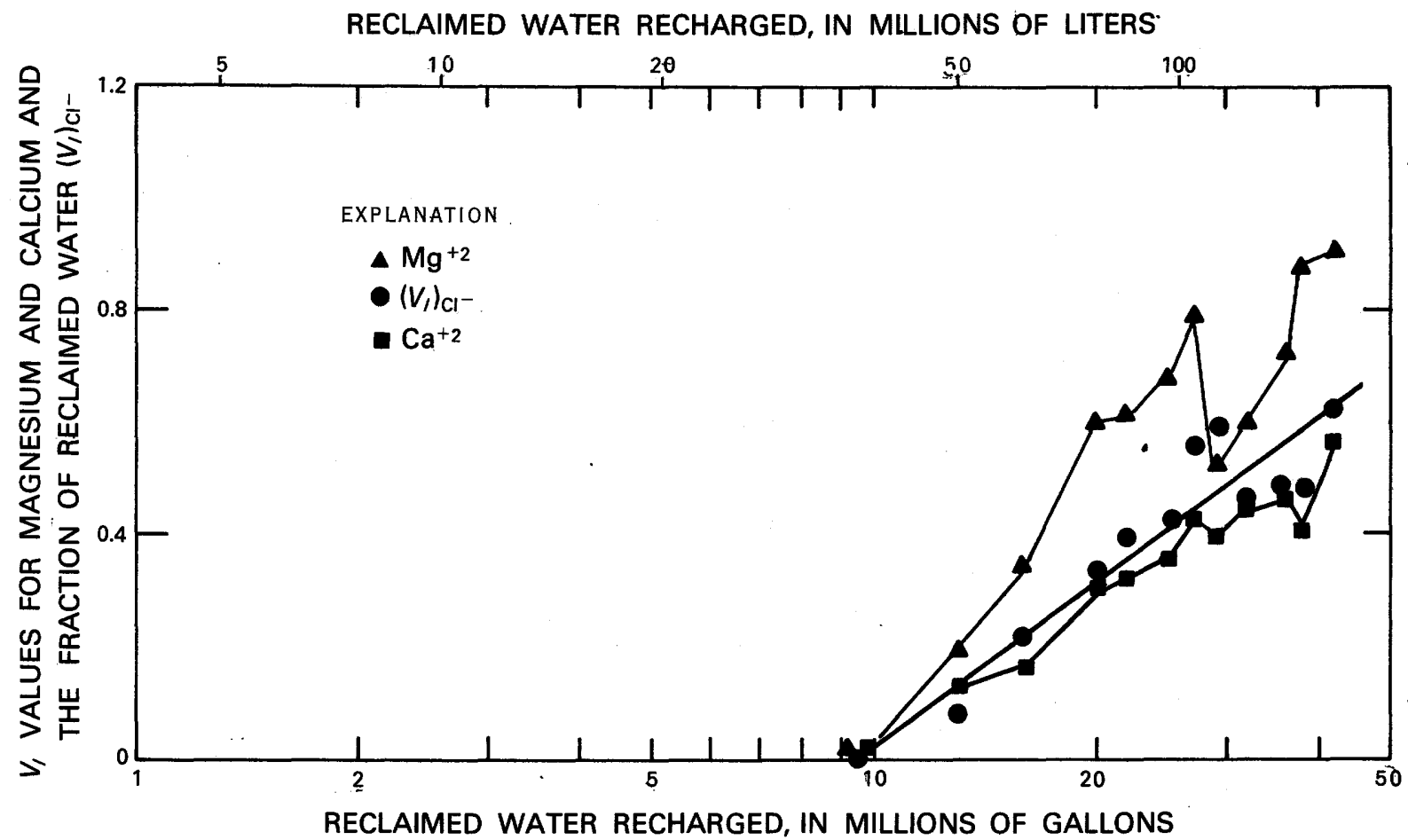

FIGURE 11.-Changes in $V_{I}$ values for calcium and magnesium as a function of the fraction of reclaimed water $\left(V_{l}\right)_{\left(1^{-}\right.}$at the 200foot (61-meter) observation well during recharge.

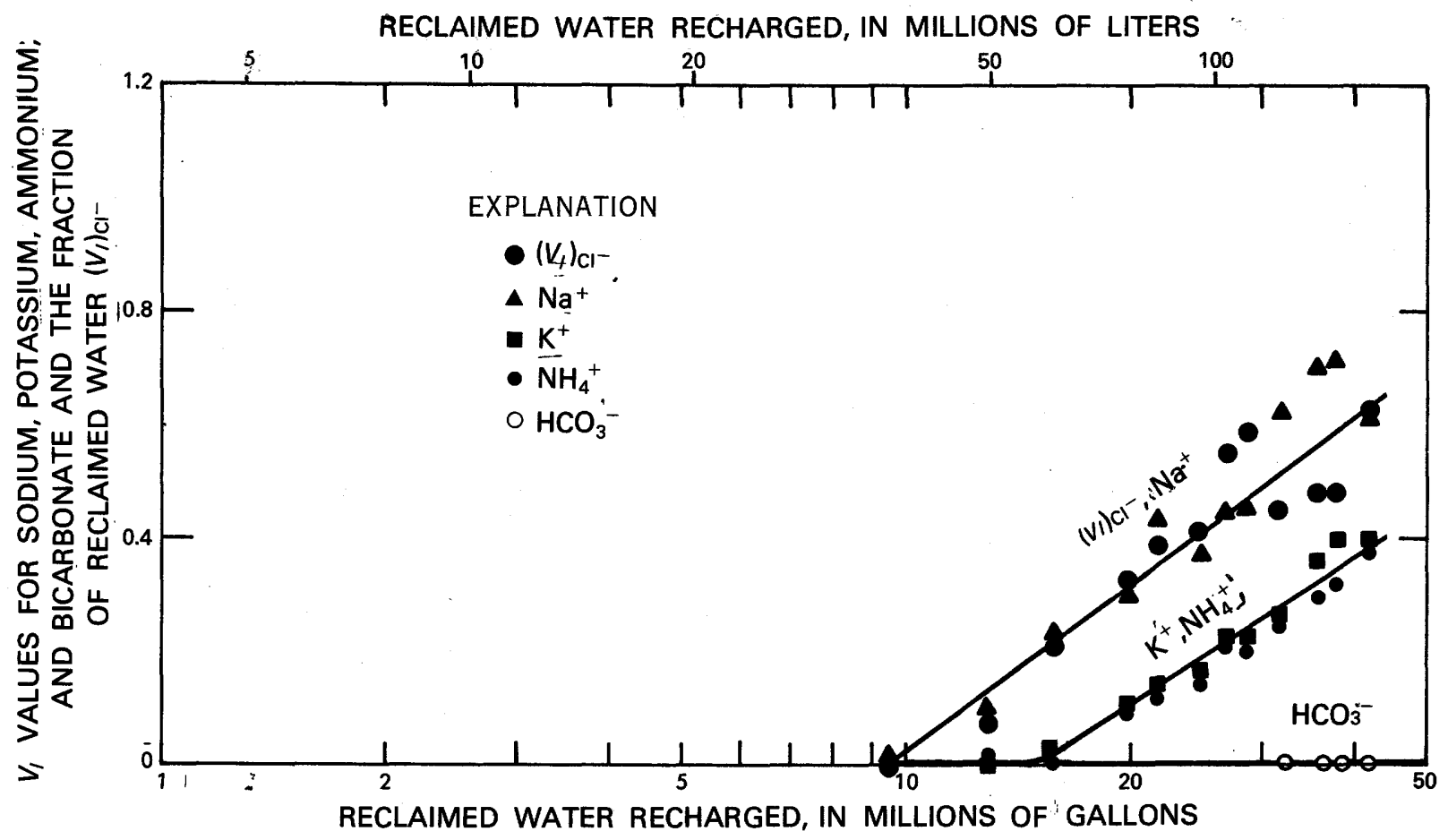

FIGURE 12.-Changes in $V_{I}$ values for sodium, potassium, ammonium, and bicarbonate as a function of the fraction of reclaimed water $\left(V_{l}\right)_{\mathrm{Cl}^{-}}$at the 200-foot (61-meter) observation well during recharge. 
TABLE 9.-Differences between observed and calculated concentrations of calcium, magnesium, sodium, potassium, ammonium; and hydrogen ions in water from the 200-foot (61-meter) observation well

\begin{tabular}{|c|c|c|c|c|c|c|c|c|c|c|c|c|}
\hline \multirow{3}{*}{ Constituents } & \multicolumn{12}{|c|}{ Volume of water injected, in million of gallons } \\
\hline & \multicolumn{2}{|c|}{13} & \multicolumn{2}{|c|}{16} & \multicolumn{2}{|c|}{20} & \multicolumn{2}{|c|}{22} & \multicolumn{2}{|c|}{25} & \multicolumn{2}{|c|}{27} \\
\hline & Difference & $\begin{array}{l}\text { Percentage } \\
\text { difference }\end{array}$ & Difference & $\begin{array}{l}\text { Percentage } \\
\text { difference }\end{array}$ & Difference & $\begin{array}{l}\text { Percentage } \\
\text { difference }\end{array}$ & Difference & $\begin{array}{l}\text { Percentage } \\
\text { difference }\end{array}$ & Difference & $\begin{array}{l}\text { Percentage } \\
\text { difference }\end{array}$ & Difference & $\begin{array}{l}\text { Percentage } \\
\text { difference }\end{array}$ \\
\hline $\mathrm{Ca}+2 \ldots$ & ... 0 & 0 & -0.05 & -22 & -0.02 & -6 & -0.03 & -9 & -0.06 & -16 & -0.01 & -2 \\
\hline $\mathrm{Mg}^{+2} \quad \ldots$. & $\ldots-.67$ & -151 & +.07 & +40 & $\begin{array}{r}0.02 \\
+.13\end{array}$ & +55 & +.12 & +48 & +.12 & +43 & +.16 & +52 \\
\hline $\mathrm{Na}+\ldots$. & $\ldots-.13$ & -27 & -.17 & -21 & +.01 & $\begin{array}{r}30 \\
+\quad 1\end{array}$ & +.04 & +3 & -.09 & -6 & +.01 & +1 \\
\hline & $\ldots-.04$ & -100 & -.07 & -112 & -.07 & -82 & -.06 & -67 & -.08 & -73 & -.06 & -50 \\
\hline $\mathrm{NH}_{4}+\ldots \ldots \ldots \ldots$ & $\ldots-.19$ & -181 & -.33 & -169 & -.36 & -106 & -.36 & -92 & -.44 & -94 & -.36 & -67 \\
\hline $\mathrm{H}+($ see footnote $\mathrm{l})$ & $\ldots+.14$ & +140 & +.15 & +143 & +.31 & +177 & +.33 & +178 & +.41 & +200 & +.40 & +174 \\
\hline Gain or loss ${ }^{2}$ & $\ldots-.89$ & $\ldots$ & -.40 & $\ldots$ & 0 & $\ldots$ & +.04 & $\ldots$ & -.14 & $\ldots$ & +.14 & $\ldots$ \\
\hline
\end{tabular}

\begin{tabular}{|c|c|c|c|c|c|c|c|c|c|c|}
\hline \multirow{3}{*}{ Constituents } & \multicolumn{10}{|c|}{ Volume of water injected, in millions of gallons - Continued } \\
\hline & \multicolumn{2}{|c|}{29} & \multicolumn{2}{|c|}{32} & \multicolumn{2}{|c|}{36} & \multicolumn{2}{|c|}{38} & \multicolumn{2}{|c|}{42} \\
\hline & Difference & $\begin{array}{l}\text { Percentage } \\
\text { difference }\end{array}$ & Difference & $\begin{array}{l}\text { Percentage } \\
\text { difference }\end{array}$ & Difference & $\begin{array}{l}\text { Percentage } \\
\text { difference }\end{array}$ & Difference & $\begin{array}{l}\text { Percentage } \\
\text { difference }\end{array}$ & Difference & $\begin{array}{c}\text { Percentage } \\
\text { difference }\end{array}$ \\
\hline $\mathrm{Ca}^{2} \quad \ldots$ & -0.07 & -17 & -0.06 & -11 & -0.11 & -20 & -0.21 & -35 & -0.06 & -8 \\
\hline $\mathrm{Mg}^{+2} \quad \ldots$ & +.04 & +11 & +.08 & +18 & +.13 & +25 & +.19 & +35 & +.19 & +38 \\
\hline $\mathrm{Na}+\ldots .$. &.-.04 & -2 & +.36 & +18 & +.46 & +21 & +.47 & +21 & -.03 & -1 \\
\hline &.-.06 & -50 & -.07 & -52 & -.06 & -38 & -.05 & -30 & -.07 & -40 \\
\hline $\mathrm{NH}_{4}+\ldots \ldots \ldots \ldots$ & -.38 & -75 & -.43 & -70 & -.42 & -60 & -.41 & -55 & -.38 & -46 \\
\hline $\mathrm{H}+($ see footnote 1$)$ &.+.40 & +182 & +.48 & +200 & +.45 & +164 & +.55 & +200 & +.58 & +200 \\
\hline Gain or loss $s^{2}$ &.-.11 & $\ldots$ & +.36 & $\ldots$ & +.45 & $\ldots$ & +.54 & $\ldots$ & +.23 & ... \\
\hline
\end{tabular}

${ }^{1} \mathrm{H}+$ gained by solution assumed equal to $\mathrm{HCO}_{3}$ - lost from solution, but not necessarily true in this case (see text).

${ }^{2}$ Plus sign indicates that cations have been added to solution; minus sign indicates that cations have been removed. 
1975) but an average concentration of $0.17 \mathrm{mg} / \mathrm{l}$ phosphorus (as $\mathrm{PO}_{4}$ ) remains. Concentrations of MBAS (methylene blue active substance) and COD (chemical oxygen demand) are also substantially decreased by tertiary treatment-MBAS by 98 percent and COD by 90 percent (Vecchioli and others, 1975)-which leaves average concentrations of $0.07 \mathrm{mg} / \mathrm{l}$ and $9 \mathrm{mg} / \mathrm{l}$, respectively. Denitrification is not included in tertiary treatment at Bay Park. Total $\mathbf{N}$ (total nitrogen) concentration of the reclaimed water averages $24 \mathrm{mg} / \mathrm{l}$ (as N). Of this, $23 \mathrm{mg} / \mathrm{l}$ (as N) is in $\mathrm{NH}_{4}+$ form, $0.59 \mathrm{mg} / 1$ (as $\left.\mathrm{N}\right)$ is in $\mathrm{NO}_{3}^{-}$(nitrate) form, and $0.01 \mathrm{mg} / \mathrm{l}$ (as $\mathrm{N}$ ) is in $\mathrm{NO}_{2}^{-}$(nitrite) form.
As reclaimed water reaches the $20-\mathrm{ft}(6.1-\mathrm{m})$ well, concentrations of total $\mathrm{N}$ and MBAS increase (fig. 13). The MBAS curve reaches reclaimed-water levels at nearly the same time that $\left(V_{1}\right)_{\mathrm{C}^{-}}$reaches 1 , which indicates little MBAS retention by the formation. The total $\mathbf{N}$ curve reaches reclaimed-water concentration after $\left(V_{I}\right)_{\mathrm{Cl}}$-reaches 1 , which indicates some retention. Because most of the total $\mathrm{N}$ is composed of $\mathrm{NH}_{4}^{+}$, the observed retention is explained by cation exchange, as described previously. Insufficient data are available to show changes in COD during recharge. The $\mathrm{PO}_{4}^{-3}$ curve indicates that at the 20$\mathrm{ft}(6.1-\mathrm{m})$ well the concentration of this constituent is only RECLAIMED WATER: RECHARGED, IN MILLIONS OF LITERS
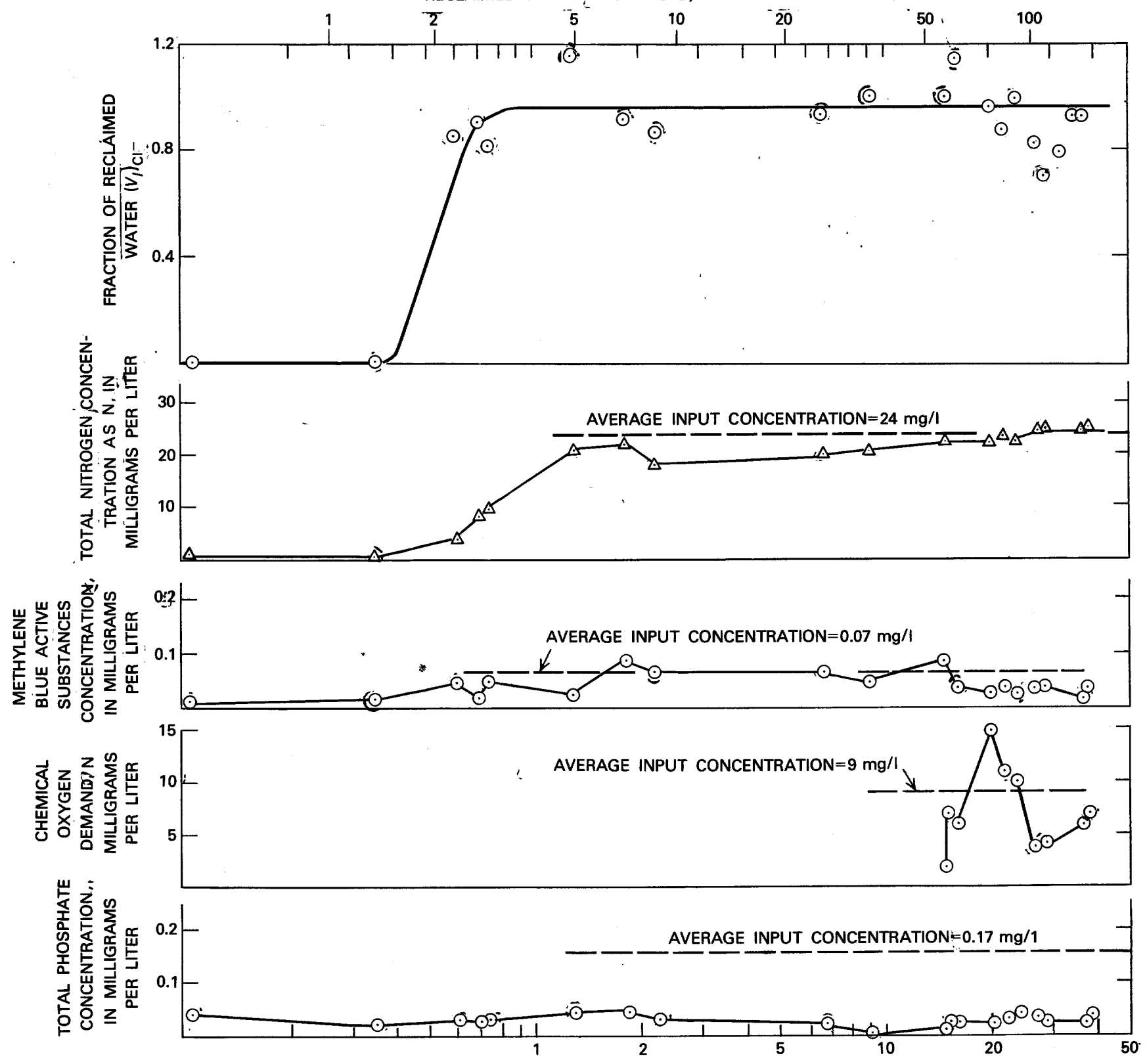

RECLAIMED WATER RECHARGED, IN MILLIONS OF GALLONS

FIGURE 13.-Changes in MBAS, total phosphate, total nitrogen, and COD concentrations as a function of the fraction of reclaimed water $\left(V_{I}\right)_{\mathrm{Cl}^{-}}$at the 20-foot (6.1-meter) observation well during recharge. 


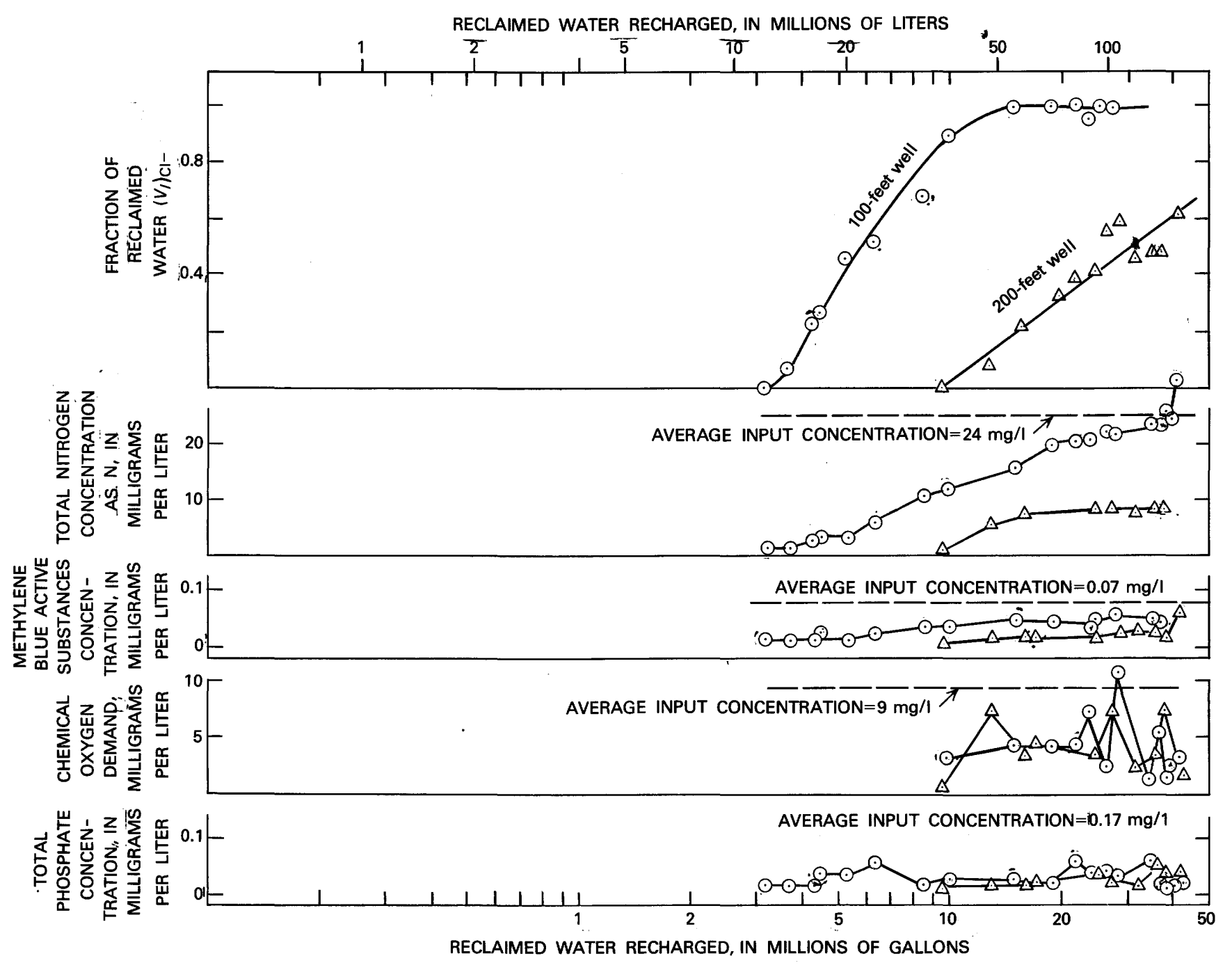

FIGURE 14.-Changes in MBAS, total phosphate, total nitrogen, and COD concentrations as a function of the fraction of reclaimed water $\left(V_{l}\right)_{\mathrm{Cl}^{-}}$at the $100-$ and 200 -foot (30- and 61-meter) observation wells during recharge.

slightly greater than the $0.01-$ to $0.02-\mathrm{mg} / \mathrm{l}$ concentration in native water but is significantly below the $0.17 \mathrm{mg} / 1$ average for reclaimed water.

Changes in the concentrations of total N, MBAS, COD, and total $\mathrm{PO}_{4}^{-3}$ at the $100-\mathrm{ft}(30-\mathrm{m})$ and $200-\mathrm{ft}(61-\mathrm{m})$ wells during recharge are plotted in figure 14. Total $\mathrm{N}$ behaves as described at the 20-ft $(6.1-\mathrm{m})$ well. MBAS and COD do not reach reclaimed-water levels by the end of the test, which suggests some retention by the aquifer. Total $\mathrm{PO}_{4}{ }^{-3}$ remains approximately at native-water levels.

Evidently, some pollution-indicator constituents are selectively removed in the Magothy aquifer during recharge. Total $\mathrm{N}$, mainly as $\mathrm{NH}_{4}^{+}$, is removed by cation exchange, as described earlier. $\mathrm{PO}_{4}^{-3}$ is presumably removed by precipitation with $\mathrm{Ca}^{+2}, \mathrm{Al}^{+3}$, or $\mathrm{Fe}^{+3}$, all of which are very insoluble salts at prevailing $\mathrm{pH}$ values
(Leckie and Stumm, 1970), or by adsorption on clay in the aquifer. Decreases in concentrations of MBAS and COD can also probably be attributed to adsorption.

\section{SUMMARY}

Determination of the kind and extent of chemical reactions between reclaimed water and native water and aquifer minerals was one phase of the experimental recharge studies at Bay Park.

Secondary-treated sewage was diverted from the Bay Park sewage-treatment plant to a pilot tertiary-treatment plant, where physical and chemical treatment produced an effluent that met virtually all standards for drinking water, as established by the U.S. Public Health Service (1962). 
Tertiary-treated effluent was pumped $0.5 \mathrm{mi}(0.8 \mathrm{~km})$ to the recharge facility, which included an 18-in $(46-\mathrm{cm})$ diameter recharge well screened at a depth of 418 to $480 \mathrm{ft}$ (127 to $146 \mathrm{~m}$ ), and 18 observation wells ranging from several inches to $200 \mathrm{ft}(61 \mathrm{~m})$ from the recharge well and screened at different depths above, below, and in the recharge zone.

Thirteen recharge experiments with reclaimed water and six with city water were completed between 1968 and 1973. Most of the data reported were collected during the last and longest test, in which reclaimed water was injected on 84.5 days of a 199-day period between October 24, 1972, and May 11, 1973, but additional data from other tests are also included. Most of the samples were taken from three wells located 20, 100, and $200 \mathrm{ft}(6.1,30$, and $61 \mathrm{~m})$, respectively, from the recharge well. Test results are summarized as follows:

1. Samples taken from three wells screened in the recharge zone 20,100 , and $200 \mathrm{ft}(6.1,30$, and $61 \mathrm{~m})$ from the recharge well indicated that chemical reactions were altering the reclaimed water passing through the aquifer.

2. The observed increase in iron concentration from less than $0.5 \mathrm{mg} / 1$ to $3 \mathrm{mg} / 1$ in the reclaimed-water front indicates interaction between a constituent of the reclaimed water and the pyrite and marcasite $\left(\mathrm{FeS}_{2}\right)$ in the aquifer. Pyrite and marcasite are the only sources of iron large enough to provide the amount taken into solution. Iron was taken into solution near the $20-\mathrm{ft}(6.1-\mathrm{m})$ well by reaction of $\mathrm{FeS}_{2}$ with dissolved oxygen in the reclaimed water, but, as reclaimed water becomes devoid of oxygen beyond the $20-\mathrm{ft}(6.1-\mathrm{m})$ well, the continued pickup of iron is not quantitatively understood.

3. There seems to be an exchange between $\mathrm{NH}_{4}^{+}$and $\mathrm{K}^{+}$ in the water and $\mathrm{H}^{+}$on the clays. Concentrations of $\mathrm{Ca}^{+2}$ and $\mathrm{Mg}^{+2}$ are greater than had been predicted from a simplified aquifer flow model.

4. Movement of pollutant-indicator constituents (MBAS, COD, and $\mathrm{PO}_{4}^{-3}$ ) was monitored. $\mathrm{PO}_{4}^{-3}$ was retained by the aquifer. MBAS and COD were partly retained at distances of 100 and $200 \mathrm{ft}(30$ and $61 \mathrm{~m})$ from the recharge well.

\section{REFERENCES CITED}

Cohen, Philip, and Durfor, C. N., 1966, Design and construction of a unique injection well on Long Island, N.Y., in Geological Survey research 1966: U.S. Geol. Survey Prof. Paper 550-D, p. D253-D257. 1967, Artificial-recharge experiments utilizing renovated sewage-plant effluent-a feasibility study at Bay Park, New York, U.S.A.: Internat. Assoc. Sci. Hydrology Pub. 72, p. 194-199.

Cohen, Philip, Franke, O. L., and Foxworthy, B. L., 1968, An atlas of Long Island's water resources: New York State Water Resources Comm. Bull. 62, 117 p.

Ehrlich, G. G., Ehlke, T. A., and Vecchioli, John, 1972, Microbiological aspects of ground-water recharge-injection of purified chlorinated sewage effluent in Geological Survey research 1972: U.S. Geol. Survey Prof. Paper 800-B, p. B241-B245.

1973, Microbiological aspects of ground-water rechargeinjection of purified unchlorinated sewage effluent at Bay Park, Long Island, New York: U.S. Geol. Survey Jour. Research, v. 1, no. 3, p. 341-344.

Faust, S. D., and Vecchioli, John, 1974, Chemical problems associated with the injection of highly treated sewage into a deep-sand aquifer: Am. Water Works Assoc. Jour., v. 66, no. 6, p. 371-377.

Franke, O. L., and Cohen, Philip, 1972, Regional rates of ground-water movement on Long Island, New York in Geological Survey research 1972: U.S. Geol. Survey Prof. Paper 800-C, p. C271-C277.

Franke, O. L., and McClymonds, N. E., 1972, Summary of the hydrologic situation on Long Island, New York, as a guide to water-management alternatives: U.S. Geol. Survey Prof. Paper 627-F, 59 p.

Koch, Ellis, Giaimo, A. A., and Sulam, D. J., 1973, Design and operation of the artificial-recharge plant at Bay Park, New York: U.S. Geol. Survey Prof. Paper 751-B, p. B1-B14.

Ku, H. F. H., Vecchioli, John, and Ragone, S. E., 1975, Changes in concentration of certain constituents in treated waste water during movement through the Magothy aquifer, Bay Park, New York: U.S. Geol. Survey Jour. Research, v. 3, no. 1, p. 89-92.

Leckie, James, and Stumm, Werner, 1970, Phosphate precipitation, in Gloyna, E. F., and Wesley, W. W., Jr., eds., Water quality improvement by physical and chemical processes, 1970, Center for Research in Water Resources, Research Symposium 3, p. 237-249.

Pearson, F. J., Jr., and Friedman, Irving, 1970, Sources of dissolved carbonate in an aquifer free of carbonate minerals: Water Resources Research, v. 6, no. 6, p. 1775-1781.

Perlmutter, N. M., and Geraghty, J. J., 1963, Geology and ground-water conditions in southern Nassau and Southeastern Queens Counties, Long Island, New York: U.S. Geol. Survey Water-Supply Paper 1613-A, $205 \mathrm{p}$.

Perlmutter, N. M., Pearson, F. J., Jr., and Bennett, G. D., 1968, Deep-well injection of treated waste water-an experiment in re-use of ground water in western Long Island: New York State Geol. Assoc., Guidebook 40th Ann. Mtg., p. 221-231.

Peters, J. H., and Rose, J. L., 1968, Water conservation by reclamation and recharge: Am. Soc. Civil Engineers Proc., Sanitary Eng. Div. Jour., v. 94, no. SA4, p. 625-639.

Ragone, S. E., Ku, H. F. H., and Vecchioli, John, 1975, Mobilization of iron in water in the Magothy aquifer during long-term recharge with tertiary-treated sewage, Bay Park, New York: U.S. Geol. Survey Jour. Research, v. 3, no. 1, p. 93-98.

Ragone, S. E., and Vecchioli, John, 1975, Chemical interaction during deep-well recharge, Bay Park, New York: Ground Water, v. 13, no. l, p. 17-24.

Ragone, S. E., Vecchioli, John, and Ku, H. F. H., 1973, Short-term effect of injection of tertiary-treated sewage on iron concentration of water in Magothy aquifer, Bay Park, New York, in Underground waste management and artificial recharge, v. 1., Second Internat. Symposium on Underground Waste Management and Artificial Recharge, New Orleans, La., p. 273-290 (preprint).

Temporary State Commission on the Water Supply Needs of Southeastern New York, 1972, Scope of public water-supply needs: Albany, N.Y., $250 \mathrm{p}$.

Truesdall, A. H., and Jones, B. F., 1974, WATEQ, a computer program for calculating chemical equilibria in natural waters: U.S. Geol. Survey Jour. Research, v. 2, no. 2, p. 233-248.

U.S. Public Health Service, 1962, Drinking water standards, 1962: U.S. Public Health Service Pub. 956, 61 p.

Vecchioli, John, 1970, A note on bacterial growth around a recharge well at Bay Park, Long Island, New York: Water Resources Research, v. 6, no. 5, p. 1415-1419. 
1972, Experimental injection of tertiary-treated sewage in a deep well at Bay Park, Long Island, New York-a summary of early results: New England Water Works Assoc. Jour., v. 86, no. 2, p. 87103.

Vecchioli, John, Bennett, G. D., Pearson, F. J., Jr., and Cerrillo, L. A., 1974, Geohydrology of the artificial recharge site at Bay Park, Long Island, New York: U.S. Geol. Survey Prof. Paper 751-C, 29 p.

Vecchioli, John, Ehrlich, G. G., and Ehlke, T. A., 1972, Travel of pollution-indicator bacteria through the Magothy aquifer, in Geological Survey research 1972: U.S. Geol. Survey Prof. Paper 800B, p. B237-B239.

Vecchioli, John, and Giaimo, A. A., 1972, Corrosion of well-casing and screen metals in water from the Magothy aquifer and in injected reclaimed water, Bay Park, Long Island, N.Y., in Geological Survey research 1972: U.S. Geol. Survey Prof. Paper 800-B, p. B247-B251.

Vecchioli, John, and Ku, H. F. H., 1972, Preliminary results of injecting highly treated sewage-plant effluent into a deep sand aquifer at Bay Park, New York: U.S. Geol. Survey Prof. Paper 751-A, 14 p.

Vecchioli, John, Oliva, J. A., Ragone, S. E., and Ku, H. F. H., 1975, Recharge of reclaimed wastewater, Bay Park, New York: Am. Soc. Civil Engineers Proc., Environmental Eng. Div. Jour., v. 101, no. EE2, p. 201-214.

Walton, George, 1951, Survey of literature relating to infant methoglobinemia due to nitrate-contaminated water: Am. Jour. Public Health, v. $41,986 \mathrm{p}$.

is U.S. Government Printing Office: 1977-240-961/115 

